\title{
EXITING AND ENTERING RELATIONSHIPS: A FRAMEWORK FOR RE-ENCOUNTERS IN BUSINESS NETWORKS
}

\begin{abstract}
In the networked business environment, the same actors come together and part in various situations. Addressing this, existing research describes the lifecycle of business relationships and network participation: Stages from relationship formation to termination and network exits have been covered. Less is known about the phases following a termination of relationships in networks. Especially, literature is relatively silent on those situations where the actors' paths cross again after a past exit. That is, re-encounters remain poorly understood.

Building on existing literature and illustrative examples on business networks and relationships, this conceptual study suggests that a longitudinally integrated view connecting the exit and post-exit developments to later encounters is needed. This study points out that the crossing of paths may, or may not, give start to the re-establishment of business relations, depending on the re-encounter itself and the preceding steps. Moreover, it is suggested that these antecedents derive from individual, organizational, relationship, and network levels. Therefore a vertically integrated approach further explains the re-encounter outcomes. The aim is to capture dynamics behind re-encounter outcomes - categorized here as (1) refraining from future interaction, (2) retribution, (3) reactivation characterized by reframing, or (4) full reactivation of relationships and collaboration - to assist future research.
\end{abstract}

Keywords: business network, exit, relationship termination, re-encounter, reactivation 


\section{INTRODUCTION}

Inter-organizational business and innovation networks (see, e.g., Möller and Rajala, 2007; Uzzi, 1997) are in a constant state of more or less rapid change: Connections are created, become activated and go dormant (Hadjikhani, 1996; Skaates et al., 2002; Vorley, Mould and Courtney, 2012), relationships change their nature, new commitments are made, and actors move between central and more peripheral positions (Chou and Zolkiewski, 2012; Fors and Nyström, 2009; Möller and Rajala, 2007). Accordingly, considerable amount research has been done on initiation, evolution, and the endings of relationships (Gidhagen and Havila, 2014; 2016). Earlier research covers, for example, the building of various types of business networks, network orchestration and antecedents of relationship termination, and it emerges in a range of research streams, from social psychology to organizational and network theories (see, e.g., Barlow, Roehrich and Wright, 2013; Dhanaraj and Parkhe, 2006; Halinen and Tähtinen, 2002; Håkansson and Ford, 2002; Grayson and Ambler, 1999; Gulati, Sytch and Mehrotra, 2008; Oliver and Ebers, 1998; Provan, Fish and Sydow, 2007; Ritter, 1999; Ritter, Wilkinson and Johnston, 2004).

However, gaps still exist in the current knowledge on network dynamics. Mitrega et al. (2012, 739) refer to one of them when they note that "the main focus [of inter-organizational marketing and supply chain management] is on tools to strengthen existing relationships with suppliers and buyers. Managing the origins of business relationships, as well as the ending of relationships, does not receive the same amount of attention (Edvardsson et al., 2008; Joshi and Stump, 1999; Tahtinen and Halinen, 2002)." [Emphases in the original]. Relatedly, research devoted to understanding the ways of dealing with different relational shifts (e.g., Brattström et al., 2013; Faems et al., 2008; Tähtinen and Vaaland, 2006) seems to hold specific emphases: As the building of relationships is costly and challenging, attention has often been paid to figuring out how networks can be managed so as to overcome problems and ensure continuation, rather than to effects of exits (Ariño and de la Torre, 1998; Garland, 1990; Guler, 2007; Halinen and Tähtinen, 2002; Zhang, Griffith and Cavusgil, 2005). In line with this, Gidhagen and Havila (2016) suggest that the so-called aftermath stage following relationship termination is poorly covered in the existing literature. Various consequences from positive to negative (e.g., gaining freedom to focus on utilizing the strengths of the organization; loss of access to markets), from direct to indirect, and from immediate to delayed (e.g., delivery problems; effects on innovativeness or new relationship formation) may result from relationship termination and network 
exit (see, e.g., Dirks, Lewicki and Zaheer, 2009; Halinen and Tähtinen, 2002), but the related dynamics are not necessarily clear.

Understanding the effects of the exit and post-exit stages is important especially considering that business relationships can become activated again after a more silent period, and that beneficial outcomes may be related to re-establishing relationships (Gidhagen and Havila, 2016; Mariotti and Delbridge, 2012) ${ }^{1}$. However, earlier research does not really go beyond acknowledging that earlier connections are somehow relevant in partner selection and further collaboration (see Li et al., 2008; Levin, Walter and Murnighan, 2011; Zhelyazkov and Gulati, 2016). It seems that a disconnection exists between exit and entry studies.

Due to the tendency to consider the start and end of relationships to reside at opposite ends of a continuum (and to emerge chronologically in this order), temporal gaps and their role in interactor connections are not always fully acknowledged (Michailova and Paul, 2014). In particular, a lack of knowledge seems to burden understanding of the full range of situations in which the paths of actors that have been involved in an earlier exit cross again; these are labelled in this study as re-encounters. Other alternatives than network participation and relationship reactivation resulting from these situations, such as turning down an offer to start collaboration, and the factors driving them are rarely addressed (see e.g., Zhelyazkov and Gulati, 2016). Taking a step toward filling this gap, a re-encounter is understood here widely. It is suggested that re-encounters can cover not only the reactivation of earlier relationships, but also include situations where relationships are not re-established; the parties briefly meet/interact, and then continue on separate paths. Networks are not necessarily entered again after exit. Noteworthy is that even in these cases, the re-encounter may change the direction of business operations for one or all of the parties (e.g. making opportunities available or denying them), but such effects are not self-evident: it may be that re-encounters have no visible effect on later developments. Re-encounter outcomes vary.

This study takes the initiative in examining re-encounter-related outcomes conceptually. In particular, it aims to describe how different re-encounter outcomes develop from earlier network

\footnotetext{
${ }^{1}$ Acknowledging this, some research covers reactivation of inactive relationships and identifies the related benefits, such as faster start of efficient business exchange, enhanced access to potentially critical resources, or relatively low relationship development investments (see, e.g., Hadjikhani, 1996; Pressey and Mathews, 2003; Pick, 2010; Poblete, Bengtson, and Havila, 2014; Skaates et al., 2002; Tidström and Åhman, 2006; Tokman, Davis and Lemon, 2007; Tähtinen, 2002; Vorley et al., 2012).
} 
exits and relationship terminations. It is argued that each step forward after an exit could turn the direction toward a different re-encounter outcome. The approach taken is deliberately broad, and the terms 'relationship ending' or 'termination' and 'exit from a network' are used interchangeably: while it is acknowledged that exiting networks and individual relationships are conceptually different - with network exit necessitating relationship ending $(s)^{2}$, but relationship termination not necessarily meaning that exit from a network would occur - this study focuses more on the general patterns. Likewise, while it is likely that variation in network dynamics exists when different networks are considered ${ }^{3}$, here 'networks' refer to strategic business and/or innovation networks where actors are identifiable and where the existing ties are strategically important (see Alajoutsijärvi et al., 1999; Jarillo, 1988; Gulati et al., 2000).

In line with the broad view, it is further suggested that the re-encounter outcomes can derive from different levels, with the organizational level reflecting individuals' perceptions and behavior, organizational aspects affecting business relationships, and relationship dynamics influencing whole networks, for example (see e.g., Granovetter, 1985; Halinen, Salmi and Havila, 1999; Hertz, 1998; Salo, Tähtinen and Ulkuniemi, 2009). While it is acknowledged in earlier studies that different level factors bear importance - especially since the effects of critical events affecting relations and their development, such as exits, spread from one level to another (e.g., Brattström et al., 2013; Dahlin and Havila, 2009) - how they exactly affect re-encounter outcomes is not well known ${ }^{4}$.

Addressing these issues is of relevance, as conceptual tools for approaching re-encounter outcomes analytically ease the understanding of what is going on in business networks and the relationships within. Likewise, being able to make sense of the links between re-encounter outcomes and earlier developments improves recovery from past problems, or allows actors to efficiently build on the best practices.

\footnotetext{
${ }^{2}$ Relationship termination may cause multiple chain reactions of different strength.

${ }^{3}$ Consider, for example, interpersonal networks (e.g., Ma, Yao and Xi, 2009; Peng and Luo, 2000), relatively fuzzy innovation ecosystems (Nätti, Hurmelinna-Laukkanen and Johnston, 2014), or public-private partnerships, and the related risk allocation, or networks with different emphases on contractual and relational governance (see, e.g., Roehrich, Lewis and George, 2014; Zheng, Roehrich, and Lewis, 2008).

${ }^{4}$ Often, existing studies also tend to focus on specific levels of analyses, and vertical integration is missing. Lumineau et al. $(2015,42)$, for example, note that whereas "inter-personal conflicts have attracted much attention from scholars and practitioners over the last two decades, our understanding of inter-organizational conflicts remains limited" (see also Edvardsson et al., 2014).
} 
The remainder of this paper is structured as follows: First, re-encounter situations and their outcomes are separated conceptually, and their relationship is discussed. Re-encounters and their outcomes are then tied to the steps preceding the re-encounter and to the earlier exits, with the underlying attempt to introduce a longitudinal approach that complements the traditional relationship lifecycle. This discussion covers the attributes and antecedents of exits, and the role of post-exit developments. Illustrative examples (see Appendix for a summary table) are provided, and propositions drafted throughout the paper to address the underlying dynamics, and to consider the relevance of influencing factors at different levels of analysis. Such a vertically integrative approach - next to the longitudinal one - allows for the capture of network dynamics from multiple points of view. The concluding remarks close the discussion and provide direction for future research.

\section{PRIOR LITERATURE ON BUSINESS RELATIONSHIP DYNAMICS}

Re-encounters, i.e., situations in which the paths of actors that have been involved in an earlier exit cross again, are next to inevitable in the networked business environment where organizations can belong to multiple networks, clusters or ecosystems, and where they are connected through complex webs of relationships (Batonda and Perry, 2003; Mariotti and Delbridge, 2012; Shipilov and Li, 2012). Re-encounters include but also go beyond the reactivation of earlier relationships (e.g., Gidhagen and Havila, 2016; Hadjikhani, 1996; Pressey and Mathews, 2003; Pick, 2010; Poblete et al., 2014): They cover a wide range of circumstances where earlier collaborators interrelate in the markets - not just in dyadic relationships, but also in triadic and more complex settings (see, e.g., Salo et al., 2009; Zhelyazkov and Gulati, 2016). In each of these situations, multiple actors are potentially affected directly and/or indirectly, and different outcomes may result from the re-encounters (see Fors and Nyström, 2009; Dahlin and Havila, 2009). Therefore, it is important to understand re-encounters and their premises, especially the earlier exit and the following phases preceding a re-encounter.

It is suggested here that a comprehensive approach is needed to fully understand re-encounters, and that for this, various views need to be combined. Although it is challenging to find studies with wide-ranging descriptions that would focus specifically on re-encounters and the factors affecting their outcomes, pieces of useful information for identifying relevant factors can be found scattered in different streams of research such as network theory (see Håkansson and Snehota, 1989), stage theory (e.g., Dwyer, Schurr, and Oh, 1987), state theory (e.g., Ford and 
Rosson, 1982), joinings theory (see Batonda and Perry, 2003), organizational theories (see e.g., Gulati, 1998; Zhelyazkov and Gulati, 2016), entrepreneurship literature (e.g., Ucbasaran et al., 2013), extended resource-based view (e.g., Lavie, 2006) and relational theory (e.g., Dyer and Singh, 1998). Within these streams, earlier studies have provided the basis in explaining different steps from the formation of relationships and networks to their termination (and even beyond). Existing literature further suggests that the level of analysis - individual, organizational, relational and network - is relevant. Table 1 shows some examples of studies addressing different parts of the longitudinal (relationship lifecycle) and vertical (different levels) dimensions.

Table 1. Examples of earlier literature providing guidance for understanding re-encounters

\begin{tabular}{|c|c|c|c|c|c|}
\hline & \multicolumn{3}{|c|}{ Phase of relationship/network lifecycle } & \multirow[b]{2}{*}{$\begin{array}{l}\text { ex post exit/ } \\
\text { termination }\end{array}$} \\
\hline & & initiation & $\begin{array}{l}\text { development/ } \\
\text { management }\end{array}$ & $\begin{array}{l}\text { termination/ } \\
\text { discontinuation }\end{array}$ & \\
\hline \multirow[t]{2}{*}{$\begin{array}{l}\text { Level of } \\
\text { analysis }\end{array}$} & network & $\begin{array}{l}\text { Bergenholtz and } \\
\text { Waldstrøm } 2011 \\
\text { Mitrega et al. } \\
2012 \\
\text { relationship- } \\
\text { based issues; } \\
\text { willingness to } \\
\text { share knowledge } \\
\text { Ritter 1999; } \\
2000 \\
\text { Wu and Barnes } \\
2011\end{array}$ & $\begin{array}{l}\text { Halinen et al } 1999 \\
\text { relevance of dif- } \\
\text { ferent levels } \\
\text { Mitrega et al. } \\
2012 \\
\text { conflict manage- } \\
\text { ment } \\
\text { Ring and Van de } \\
\text { Ven } 1994\end{array}$ & $\begin{array}{l}\text { Halinen et al } 1999 \\
\text { critical events } \\
\text { Halinen and } \\
\text { Tähtinen } 2002 \\
\text { reputation effects } \\
\text { Mitrega et al. } \\
2012 \\
\text { relevance of dif- } \\
\text { ferent stages } \\
\text { Zaheer et al } 2010\end{array}$ & $\begin{array}{l}\text { Gidhagen } \\
\text { and Havila, } \\
2016 \\
\text { changes in } \\
\text { networks }\end{array}$ \\
\hline & $\begin{array}{l}\text { relation- } \\
\text { ship }\end{array}$ & $\begin{array}{l}\text { Aarikka-Sten- } \\
\text { roos } 2008 \\
\text { actor activity } \\
\text { and need; third } \\
\text { party involve- } \\
\text { ment; intention- } \\
\text { ality; opportuni- } \\
\text { ties in dormant } \\
\text { relationships } \\
\text { Gulati } 1995 \\
\text { Kamp } 2005 \\
\text { Wu and Barnes } \\
2011 \\
\text { Ritter } 1999 \\
\text { Pressey and } \\
\text { Mathews } 2003 \\
\text { removal of ob- } \\
\text { stacles to col- } \\
\text { laboration }\end{array}$ & $\begin{array}{l}\text { Brattström et al } \\
2013 \\
\text { repairing trust } \\
\text { Holmlund- } \\
\text { Rytkönen and } \\
\text { Strandvik } 2005 \\
\text { Halinen et al } 1999 \\
\text { circular mecha- } \\
\text { nisms of change } \\
\text { Lumineau et al } \\
2015 \\
\text { conflict; contra- } \\
\text { diction } \\
\text { Ring and Van de } \\
\text { Ven } 1994 \\
\text { relational aspects }\end{array}$ & $\begin{array}{l}\text { Coughlan et al. } \\
2003 \\
\text { Pressey and } \\
\text { Mathews } 2003 \\
\text { irrevocability } \\
\text { Salo et al } 2009 \\
\text { role of third actor } \\
\text { Halinen et al } 1999 \\
\text { critical events } \\
\text { Halinen and } \\
\text { Tähtinen } 2002 \\
\text { planned termina- } \\
\text { tion } \\
\text { Holmlund and } \\
\text { Hobbs } 2009 \\
\text { unwillingness to- } \\
\text { ward relationship } \\
\text { retrieval } \\
\text { Tähtinen and } \\
\text { Vaaland } 2006 \\
\text { losses } \\
\text { Zaheer et al } 2010 \\
\text { potential for re- } \\
\text { newal }\end{array}$ & $\begin{array}{l}\text { Gidhagen } \\
\text { and Havila } \\
2014 ; 2016 \\
\text { remnants } \\
\text { Hadjikhani } \\
\text { et al } 2012 \\
\text { reactivat- } \\
\text { ing } \\
\text { dormant re- } \\
\text { lationships } \\
\text { Skaates et } \\
\text { al } 2002 \\
\text { Pick } 2010 \\
\text { relation- } \\
\text { ship recon- } \\
\text { ciliation } \\
\text { Poblete et } \\
\text { al. } 2014 \\
\text { reactiva- } \\
\text { tion not } \\
\text { possible }\end{array}$ \\
\hline
\end{tabular}




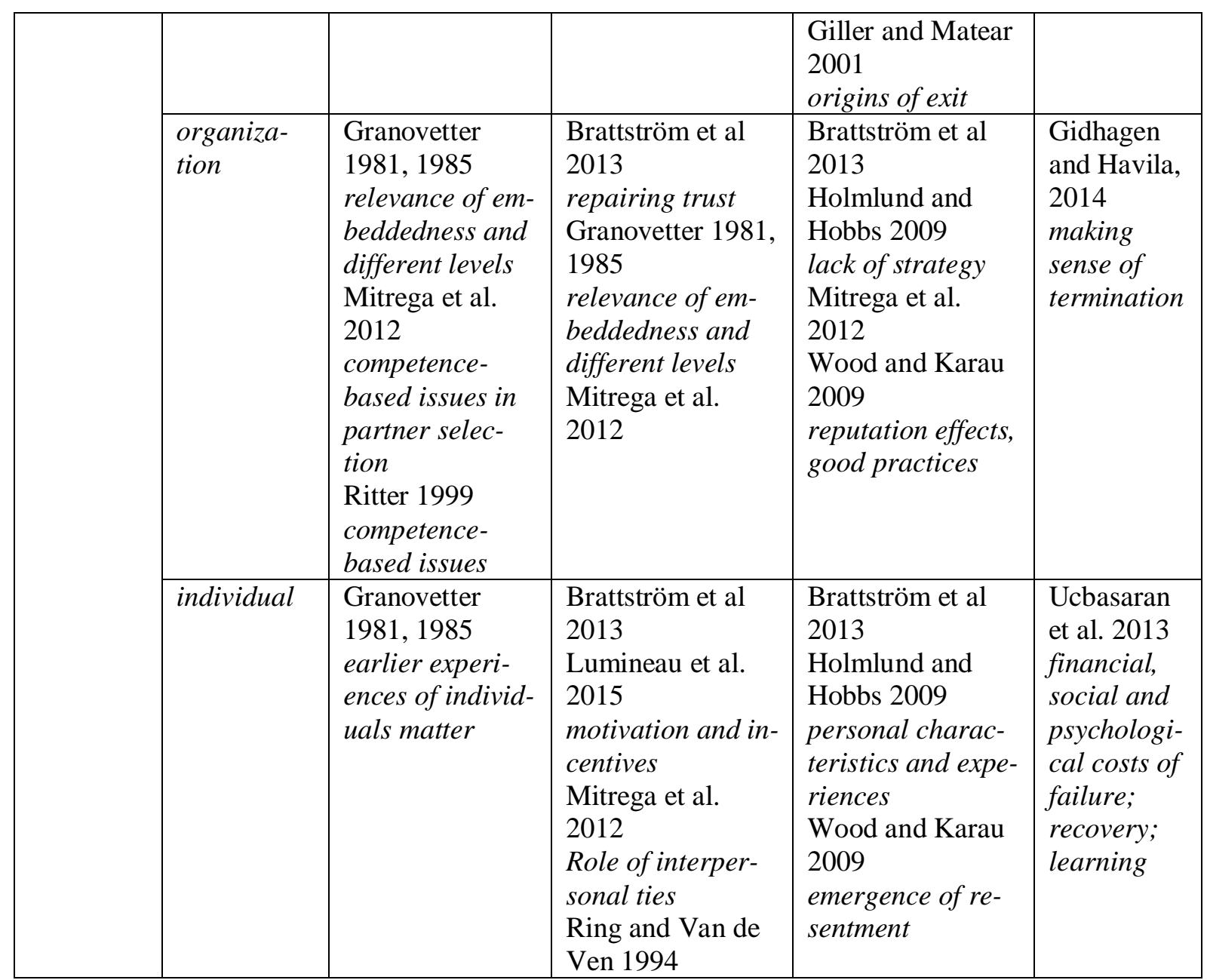

Placing existing studies in this kind of a matrix (where an individual study can touch different elements) also points towards some specific gaps in existing research. While Table 1 is not meant to be a comprehensive account of literature, it seems already from this representation that integration is still missing especially between exit and entry studies, and regarding the roles of different levels in the post exit phases. Yet, it can be argued that a longitudinally and vertically integrated view is needed to understand re-encounters and their outcomes. There are various ideas introduced in the earlier studies that can be applied at least to some extent also to reencounters, and in any case, they allow explaining the re-encounter situations and their outcomes. Table 1 provides some examples of relevant factors and concepts.

Adopting and applying ideas from prior studies, the aim of this study is to start generating a view that bridges exists to later developments, re-encounters and the steps that precede them. Figure 1 shows central points derived from earlier literature. These are discussed in the following chapters. 


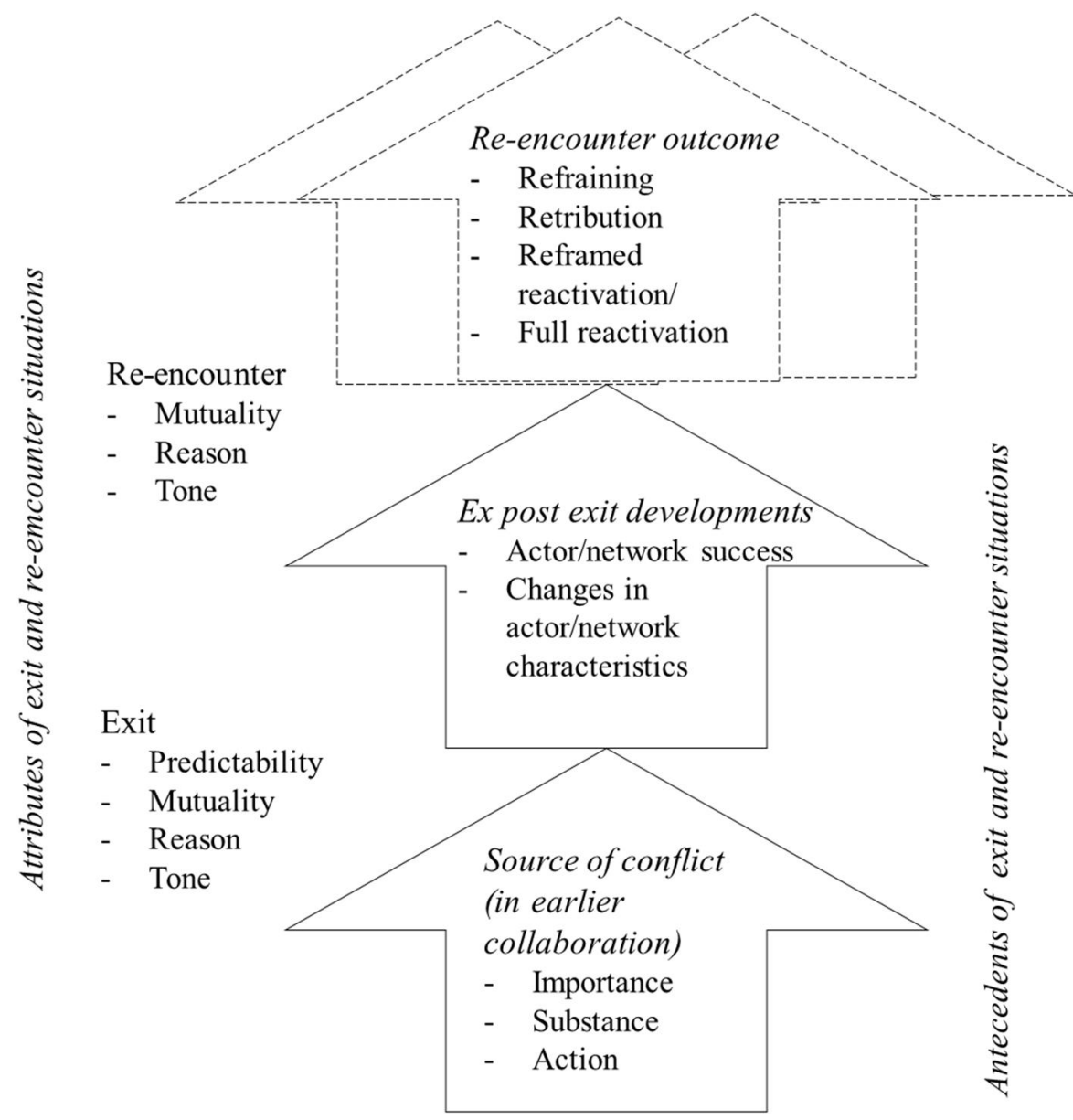

Figure 1. Exits and re-encounters, their antecedents and outcomes.

(The left side of the figure indicates specific situations (exit and re-encounter), while the arrows point toward developmental aspects).

\section{RE-ENCOUNTERS AND THEIR OUTCOMES}

The discussion on re-encounter outcomes can be started by conceptually separating re-encounter outcomes from re-encounter situations (see also Figure 1). Re-encounters can, as mentioned above, take different forms. This means that they can be considered to be characterized by specific attributes, and that they can lead to different outcomes. These are discussed below.

\subsection{Attributes of re-encounters}

Considering that re-encounters can cover a variety of situations, they may exhibit different features. Here, it is suggested that mutuality, reason, and tone are central attributes to consider. First, re-encounters can vary in terms of mutuality. It may be that just one actor initiates a reencounter by approaching others, or then it may be a result of multiple actors mutually moving 
toward each other. As an illustrative example (Example 1) ${ }^{5}$, a company developing and selling medical products had earlier conducted R\&D collaboration with a foreign company as a part of its network activity, but as the relationship dissolved, it started working on its own. As a result of their independent work, the company created an interesting invention. When the earlier partner heard about this, they contacted the innovating firm, hoping to get access to this new product. This contact can be considered a re-encounter initiated by one actor.

Second, the reasons behind the re-encounter can vary. A re-encounter that happens randomly by chance (see, e.g., Bliemel, 2011) does not necessarily put much strain on the actors. A random encounter might be, for example, related to being present in a trade fair, taking part in a stakeholder event, or being involved in the same offer competition. On the other hand, it may be that the re-encounter is opportunity-based, showing signs of benefits to be achieved (see, e.g., Rowley et al., 2015). For example, the existence of 'sleeping relationships' described by Hadjikani (1996) and Skaates et al. (2002) indicates that re-encounters can be built on perceived opportunities of returning to collaboration. ${ }^{6}$ This covers both newly emerging opportunities (e.g., related to acknowledging the importance of the other actor's competences) and the removal of (external) obstacles that have earlier led to the exit situation (Pressey and Mathews, 2003). For example, in the illustrative Example 1, the earlier partner saw benefit in contacting the inventing company again after a period of separation. Regarding the removal of obstacles, another illustrative example (Example 2) involves a situation where research funding was cut from a research consortium as a result of new rules being introduced, and where some partners were subsequently removed. A researcher noted that if funding would be returned to all parties, they would definitely start working together again (see also Kraff and Pick, 2007, on willingness to return). Yet another option is that reuniting is pursued due to necessity. A need-based re-encounter may resemble a situation characteristic to terminal relationships: Halinen and Tähtinen (2002) talk about relationships existing unwillingly, due to an inability to act independently (see also Garland, 1990). For example, it may be that earlier partners have something that cannot be accessed through other channels. Likewise, external forces may bring actors together; A necessity for re-encounter may result from location-related issues, or indirect ties

\footnotetext{
${ }^{5}$ See Appendix for a chronological description of the illustrative examples and the related theoretical concepts. ${ }^{6}$ Opportunity-related logic can also be drawn from a different stream of literature: Welch and Welch (2009) describe the events of re-internationalization after a period of time. Similar dynamics may emerge.
} 
between the parties, for example, as a result of a third party requesting specific actors to collaborate in a project (Anderson, Håkansson and Johanson, 1994; Brass, Butterfield and Skaggs, 1998; Dahlin and Havila, 2008; Shipilov and Li, 2012; Vorley et al., 2012).

A related, but distinctive dimension is the tone of the re-encounter. The re-encounter may be positive or negative, or neutral. In particular, relational aspects are relevant in this respect (Salas et al., 2015). Trustworthiness and goodwill are likely to be evaluated in re-encounter situations (see Blomqvist, Hurmelinna and Seppänen, 2005; Brattström et al., 2013). In the illustrative Example 1, the original contact by the earlier collaboration partner was not lucrative for the inventing firm, and the earlier collaborator soon copied the newly developed device, claiming the patent covering the invention to be invalid. This action gave a negative character to the reencounter.

Of the attributes described above, tone can be considered to be the likeliest attribute to be influenced by individual-level issues: earlier experiences reside in the minds of individuals, and the perceptions spread to other levels (Brattström et al., 2013; Granovetter, 1985; Nisbett and Ross, 1980). Reason and mutuality may well be individual, organizational, relationship or network-level issues. This also means that the outcomes of re-encounters can be predetermined at different levels.

\subsection{Outcomes of re-encounters}

The variety in the re-encounter attributes and their potential combinations suggests that re-encounters can lead to various outcomes, some of which involve the re-establishment of earlier connections and activities, and others that are not fruitful in terms of further collaboration. When re-encounters take place, they may initiate new developments, but not necessarily so.

\subsubsection{Refraining}

Refraining from future interaction is a likely outcome when the re-encounter is perceived as relatively indifferent and negligible, and when there is no obvious need to take action. On the other hand, it also may be that there are obstacles to restarting collaboration that cannot be removed, which leads to this outcome despite a willingness to act otherwise. For example, it may be that preferred partner organizations are unavailable due to engagements created toward third parties prior to the re-encounter, or for some other reason (Hinterhuber, 2002). 
An illustrative example (Example 3) sheds light on these situations. A firm operating in the retail sector did not get a renewal to its long-term franchise contract, meaning that the firm was discarded from its immediate network. This also meant that a supplier that had served the firm was unable, bound by contractual obligations toward the earlier franchisor, to continue deliveries to the firm. Later on, the firm got a franchise contract with another retail chain, and during a search for suppliers, the earlier business partners came into contact again. However, the contractual restrictions were still in place, meaning that refraining from collaboration with the supplier in a later re-encounter situation resulted from the persisting obstacles to collaborate. ${ }^{7}$

It also may be that the re-encounter situation has such a negative imprint that refraining is a plausible outcome. In another illustrative case (Example 4), a founder of an innovation promoting network felt that the network was being taken to the wrong direction by those who had taken over the daily network operations, and eventually he did not find any other alternative but to leave the network. He joined a new organization that turned out to be highly successful. Later on, the network representatives wanted to involve the founder's new organization in some of their activities. However, even after a long time, the founder considered these meetings with the operative network leaders to be unpleasant, and avoided collaboration. This shows how perceptions of an individual may spread throughout wider entities. The grudge held by the actors may limit future collaboration on other levels.

An individual-level or an organization-level decision to refrain from further collaboration could easily be interpreted so that the re-encounter has no impact on the relationships or the network; the status quo is not really changed. However, not starting collaboration may mean that other ties are formed within the network instead, or that a signal is sent to other network actors regarding, e.g., the trustworthiness or reliability of the actors involved (see Zhelyazkov and Gulati, 2016). Therefore, effects and adjustments may emerge across different levels.

\footnotetext{
${ }^{7}$ Refraining was the only option for the discarded firm also regarding collaboration between the firm and the earlier franchisor: According to the firm CEO, contractual arrangements with the new retail chain prevented the firm from re-joining the original franchise network, even if it might have been otherwise beneficial for the firm. However, another issue is that even if an opportunity emerged, the reactivation of the relationships would not be likely unless specific individuals deciding on the franchise contracts left the earlier franchisor firm; personal aspects were considered to be quite influential.
} 
Based on what has been said above, first propositions can be drafted regarding the relationships between re-encounters and their outcomes:

Proposition 1a: Refraining is a likely outcome of re-encounters when the re-encounter is onesided, neutral or negative, and when there is no notable opportunity or need related to it. Proposition 1b: Refraining is a likely outcome of re-encounters if negative views emerge at the time of the re-encounter at an individual level, and if they affect the organizational and relationship levels.

\subsubsection{Retribution}

The re-encounter may also give start to positive or negative actions towards the earlier partners. In the worst cases, re-encounters only serve to remind the parties about earlier negative experiences, such as a problematic exit situation, for example. Pressey and Mathews $(2003,131)$ point toward customer de-selection and supplier de-selection dissolutions typically being quite "covert with one party either undermining the relationship or else blaming the other for problems." They go on to say that this often leads "to hostility between the parties and largely irrevocable future relations." In these cases, it may be that the re-encounter initiates an active campaign against the actor that caused the exit. This may involve initiating bad publicity, for example, or trying to convince other actors in networks not to collaborate with such an organization. Retribution is a possible outcome, no matter how unwanted.

The illustrative case Example 3 has features of retribution ${ }^{8}$. In the franchise network, another franchisee had been involved in tight collaboration with the firm that was discarded. This franchisee fell into relatively minor financial problems and started discussions with the franchisor to decide how the situation could be solved. There were earlier examples of other franchisees facing similar challenges, and these situations had typically come to positive ends with the franchisees continuing to operate within the network. However, it was quite obvious that the tight connection to the discarded firm was considered a problem (even a threat), especially after the firm had joined the new retail chain: When the discarded firm tried to help the franchisee in trouble by engaging in business transactions, the franchisor took action to remove the franchisee from the network. Also, some representatives of the franchisor were spreading bad word of mouth on these two companies, very likely as a response to these firms trying to fight back.

\footnotetext{
${ }^{8}$ Therefore, the illustration also suggests that retribution can accompany refraining; the outcomes are not completely mutually exclusive.
} 
The above illustration indicates that integrity- and relationship-based problems where goodwill of other actors becomes questioned (see, e.g., Lumineau et al., 2015; Jehn, 1995) might increase the likelihood of retribution. It may even be that competence-based aspects, such as acknowledging that the other actors might be able to provide something valuable, and actual opportunities are overridden by these factors. It is likely that the problems in the individual, organizational or relationship levels contribute to retribution; at the network level, where the ties get looser and more indirect and where reputation effects (i.e., others potentially perceiving retribution as unacceptable behaviour) come into question (Tripp et al., 2002), these issues might not bear such importance. In line with this, the following is proposed:

Proposition 2a: Retribution is a likely outcome of re-encounters when the re-encounter is negative, one-sided or mutual, and when there is little or no opportunity or need related to it. Proposition 2b: Retribution is a likely outcome of re-encounters if negative aspects in the individual, organizational or relationship level emerge at the time of the re-encounter.

\subsubsection{Reframing and full reactivation}

Not all re-encounters are exceedingly negative, or sometimes retribution would simply be a bad strategy (see, e.g., Aquino et al., 2001; Tripp et al., 2002 on the complexity of retaliation). The action taken and the end-results may also have a more positive tone. In some instances a relationship reconciliation and recovery can start (see, e.g., Lopes, Brito and Alves, 2013; Pick et al., 2016).

A full reactivation of the earlier network relationships and collaboration may be possible, e.g., as a result of obstacles to continuation being removed (Hadjikhani, 1996; Skaates et al., 2002). For example, Pressey and Mathews (2003) describe a situation where earlier voluntary decisions to terminate relations lead to the revoking of the dissolution (see also Roos, 1999). This outcome can be reached if premises for the reactivation - including an adequate number of remaining connections (Mariotti and Delbridge, 2012) - are in place. A random re-encounter is hardly enough for full reactivation (although this too is a possibility), but opportunities (or need) are likely triggers. Likewise, the positive (or neutral) tone of the re-encounter more likely leads to full reactivation than a negative one. The positive approach can take place at any level from individual to network, but it is likely that for full reactivation, no negative issues can be present. 
Proposition 3a: Full reactivation is a likely outcome of re-encounters when the re-encounter is positive or neutral, one-sided or mutual, and when there is opportunity or need related to it. Proposition 3b: Full reactivation is a likely outcome of re-encounters if positive aspects at the individual, organizational or relationship level emerge at the time of re-encounter.

Full reactivation may not be practically possible, however. Mariotti and Delbridge $(2012,52)$ suggest that "The reinvigoration of [...] ties [...] often involves a redefinition of the terms of the collaboration in line with changing requirements." Network effects may be one quite decisive factor with respect to reactivation possibilities (see e.g., Vorley et al., 2012), as the network positions may be different from the earlier situation at the time of the re-encounter. As a result, reactivation characterized by reframing may become the outcome from the re-encounter.

Reframing indicates that some features of the network participation and collaboration, and the relationship are different compared to the earlier situation. It is possible that the actors start tentative collaboration through low-risk, or very specific, endeavors (see Brattström et al., 2013). Example 1 provides practical insight: In the case of the medical device developer, the need to file an infringement suit against the earlier collaboration partner (in response to copying and patent invalidity claims) and the subsequent dispute over the patent effectively led to a situation where there was no returning to the original collaborative setting. However, the patent dispute was eventually settled and as a result, the parties became bound to interaction that was not as close as in the past, but nevertheless existed.

Summarizing the above considerations, the following can be proposed:

Proposition 4a: Reframing is a likely outcome of re-encounters when the re-encounter is neutral or negative, one-sided or mutual, and when there is opportunity or need related to it. Proposition 4b: Reframing is the likely outcome of re-encounters if positive aspects in the organizational, relationship, or network level emerge at the time of the re-encounter.

The above discussion suggests that the re-encounter situation in itself is a relevant determinant of the following steps. However, there are also other factors to consider. Earlier steps, i.e., the time of separation and the earlier exit situation, may influence the outcomes as well. In fact, what has previously happened to each party comes under scrutiny in any re-encounter situation (Roos, 1999). The antecedents depicted in the middle of Figure 1 above are discussed next. 


\section{DEVELOPMENTS PRIOR TO RE-ENCOUNTER}

As suggested above, re-encounter outcomes are likely to be affected by competence-based and relational factors that define the reason and tone of the re-encounter and affect its mutuality. These factors are formed already before the re-encounter occurs. Especially the recent (ex post exit) success or failure of the actors and networks can tell about the potential for reactivating relationships - or then dismissing these possibilities. An earlier exit, especially a premature one, may give start to different implications regarding subsequent success of the parted actors (see Giller and Matear, 2001). Nevertheless, as illustrated in the middle parts of Figure 1 above, how much this eventually bears importance may depend on how much time has passed since the last contacts and, relatedly, on the kind of changes that have emerged during the time of separation (Gidhagen and Havila, 2016).

\subsection{In between exit and re-encounter - Success and failure of actors and networks}

The time of separation can be quite decisive regarding the possibilities to reactivate relationships (starting from the chance of actors meeting again): success or failure preceding a re-encounter has an effect on how the actor and network are perceived. On the one hand, actors involved in an earlier exit may have faced challenges. The notions made by Tähtinen and Vaaland (2006), for example, indicate that network actors have a lot to lose, especially when they are discarded from networks (rather than leave according to their own opportunistic agenda), or when a central actor leaves a network astray - although those parties initiating the ending of the relationship may also be hurt (see also Pick, 2010). The dissolution process can be costly, and a lot of relational investments and resources are lost, including the related time, effort and expenses (cf. Ariño and de la Torre, 1998). The loss of relation-specific resources (Dyer and Singh, 1998) and relationally developed capabilities (Collins and Hitt, 2006) means that they need to be replaced somehow, or then operations need to be adjusted so as to match the situation. The exit, set-up cost, such as searching costs, and costs related to building new relationships and connecting to new networks may burden the adjustment processes of individual actors, for example (e.g., Jones et al., 2002). Besides practical losses, the actors may have lost credibility, reputation and referrals (Alajoutsijärvi et al., 2000; Dirks et al., 2009; Halinen and Tähtinen, 2002; Hocutt, 1998). Image may have to be rebuilt if having been turned down by the earlier network or partner has left its mark in the actor's reputation (see Zhelyazkov and 
Gulati, 2016). In their study, Zhelyazkov and Gulati (2016) find that it is not only the dynamics of the relationships between the actors terminating the relationship, but the dynamics of their networks, and of their extended networks that can be affected. Combined with the need to replace lost resources and connections, reputation effects may escalate the situation notably. Relatedly, the leaving of a party may shift the network's stability and lead to other problems, even so far as dissolving the network (Vaaland, Purchase and Olaru, 2005). Such losses may carry all the way to the re-encounters if they signify that the actors are not performing to their full potential.

On the other hand, actors may be quite resilient, and they may be able to continue activities in the same field even if they have been discarded from specific networks (see Havila and Wilkinson, 2002, on these aspects at the individual level). Succeeding in 'starting anew' likely depends on the innovative and entrepreneurial capabilities of the actors (see, e.g., Rerup, 2005; Rocha, Carneiro and Varum, 2013; Sarasvathy, Menon and Kuechle, 2013). For example, during the time of separation the actors may have found new cooperation possibilities with valuable partners or new development trajectories that have been out of reach earlier (Halinen and Tähtinen, 2002). The new situation can be utilized for renewal from a new perspective, without the binding forces of the earlier network entity (cf. Håkansson and Ford, 2002). This may apply to those leaving and/or the actors remaining in networks (e.g., van der Borgh, Cloodt and Romme, 2012). In the illustrative Example 1, the medical device developer was able to produce a valuable invention that made it a potentially valuable collaboration partner. Besides relying on their own resource bases, it may also be possible for parted actors to use earlier connections even after the termination of a relationship (Gidhagen and Havila, 2014; 2016). Belonging to multiple (overlapping) networks simultaneously might facilitate this. Referring to Example 3, a representative of the firm that was discarded from the franchise network noted that feelings of resentment started to diminish after a discussion where the franchisor representatives admitted that the ending of the contract had not been handled appropriately (thereby providing a moral victory to the discarded firm), and especially after the firm was offered a new contract with another retail chain as a result of its good track record in terms of performance, in addition to its good connections to suppliers and customers. Being able to show good performance and the subsequent interest shown by third parties might become relevant in re-encounter situations (Mariotti and Delbridge, 2012). 
In all of the above situations, the level at which the influential factors reside may be important. For example, considering the illustrative Example 4 (where the new organization of the founder of a network was attracting interest of the network operative leaders), the individual-level antipathy was combined with low appreciation of the network activity, in which case refraining followed. However, the involved actors indicated that if there had been an obvious benefit in taking part in the network activity, the organization would have likely engaged in collaboration in some form. In general, it could be expected that it is the organizational or network levels where evaluation on success or failure is mainly done; competence-based issues could be highlighted in this respect. Factors at individual and relationship levels rather address the expected goodwill, for example (see Brattström et al., 2013), and may not be as decisive when the focus is on current performance level and success, and the related opportunity evaluation.

Based on the above considerations, the following propositions are introduced:

Proposition 5a: Success of actors and network during the time of separation may facilitate the development of the relationship between re-encounter and re-encounter outcomes toward full reactivation or reframing (for both direct and indirect ties)

Proposition 5b: Failures of actors and/or network during the time of separation may facilitate the development of the relationship between re-encounter and re-encounter outcomes toward refraining or retribution (especially for direct ties).

Proposition 5c: The success and failure are mainly considered at the organizational and network levels, and they can supersede relational or integrity-based problems at the individual or relationship level, especially in opportunity-or need-based re-encounters.

\subsection{Changes during the time of separation}

Individual and relationship level factors accompany organization and network level factors when the perspective is widened beyond success or failure, and especially when other premises than capabilities are also in place for the re-establishment of relationships. The time of separation is likely to introduce changes in the actor and network characteristics (see Dahlin and Havila, 2008; Vorley et al., 2012), and change perceptions and relational dynamics, which may affect the re-encounter outcomes. According to the current knowledge, ending a relationship leads to an 'aftermath stage,' during which the ending is processed and finalized (Duck, 1982; Gidhagen and Havila, 2014; 2016; Halinen and Tähtinen, 2002; Keyton, 1993; Oyer and 
Schaefer, 2000; Ping and Dwyer, 1992). This indicates that even if business activities have stopped and resource ties and actor bonds are broken, the actual process of ending is not over (Gidhagen and Havila, 2014; 2016).

During the aftermath stage, and during the following time of separation, various changes can take place. It is plausible that these emerge more easily at the network or organizational level than the individual level, where feelings likely play a bigger role. Studies on relationship repair and trust repair (e.g., Brattström et al., 2013; Griffith et al., 2006), especially at the organizational level, can provide some insight into the kinds of aspects that can turn ex post exit recovery to positive directions and thereby contribute to the development of a re-encounter where reestablishment of relationships is a possibility (Eckerd and Handley, 2015; Bachmann, Gillespie and Priem, 2015). For example, managers or contract persons who have been involved in problematic situations may be replaced with others (Brattström et al., 2013). This happened in Example 1, where settlement was only reached after the top management of the earlier collaboration partner that started the patent dispute was replaced. Interpersonal issues caused problems, and only the change in actor characteristics at organizational level allowed reframing to take place. Ownership structures may change, new resources may be acquired and capabilities developed, or the actors may engage in new networks (see Pick et al., 2016). In fact, the time of separation may also involve wider shifts in the network dynamics. A domino effect may emerge where the positions of actors in the network change (Edvardsson et al., 2014; Dahlin and Havila, 2008; Vorley et al., 2012).

Time is an important factor for these developments. The more time passes, the likelier it is that (profound) changes happen (Pick et al., 2016). One point of view is that with a longer time of separation, obstacles to collaborating have more chances to be removed, and the relationships may be reinstated (see Pressey and Mathews, 2003). As an example, unclear regulations that have earlier caused confusion may be cleared, or decisions by funding agencies can be changed so that collaboration becomes possible again. This might become the future solution for the research consortium introduced as an illustration (Example 2) above.

Likewise, the passing of time may increase the likelihood of reactivation of different types if it means that negative imprints related to initially problematic re-encounters fade away. It may be that at one point in time a re-encounter would lead to refraining or retribution, but if there is enough time for changes to take place, the problems may diminish. Time may allow changes 
even in the most persistent factors, and therefore mitigate the likelihood of retribution, for example. In fact, notions can be found in the existing literature on how the post-ending phases together with the sensemaking of earlier events secure the possibility of reactivating the earlier relationships (Pressey and Mathews, 2003; Tidtröm and Åhman, 2006; Tähtinen, 2002).

On the other hand, while research suggests that there is value in dormant connections (Levin et al., 2011; Poblete et al., 2014), it also has been noted that losing connections means that the reactivation of any relationships becomes more challenging (Gidhagen and Havila, 2014; 2016). The time of separation may change the actors and their operations environment in ways that do not accommodate the same forms of interaction as earlier (see Mariotti and Delbridge, 2012).Therefore, changes, in some cases, turn full reactivation into reframing, or even refraining. The more time passes, the more is forgotten, for better or worse (Gidhagen and Havila, 2014; 2016). Therefore, time is addressed as a part of the following propositions summarizing the above considerations.

Proposition 6a: Notable changes during the time of separation may limit the development of a relationship between re-encounter and re-encounter outcomes toward full reactivation (especially for direct ties) - instead, reframing or refraining is more likely to take place.

Proposition 6b: Lack of changes during the time of separation may facilitate the development of an initially problematic relationship between re-encounter and re-encounter outcomes toward refraining or retribution (especially for direct ties).

Proposition 6c: Notable changes during the time of separation may facilitate the development of an initially problematic relationship between re-encounter and re-encounter outcomes toward reframing (especially for indirect ties).

Proposition 6d: The longer the time of separation, the more emphasis is placed on organization-level and network-level factors (and competence-based evaluation) compared to individual-level and relationship-level factors (relational and integrity-related factors).

While these propositions cover, first and foremost, the developments during the time of separation, they also hold a reference to yet another issue that may determine the re-encounter outcomes: the attributes of the earlier exit situations and their antecedents may cast a long shadow. These are discussed in the following.

\section{EARLIER EXITS AFFECTING RE-ENCOUNTER OUTCOMES}


In this study, it is suggested that an exit in one point of time may influence the course of the forthcoming re-encounters and the following steps (see also Gidhagen and Havila, 2016). An exit corresponds to relationship endings, and takes place when no activity links exist between the parties that have been involved so far (Giller and Matear, 2001; Halinen and Tähtinen, 2002). Like re-encounters, exits can exhibit varying attributes, and they build on specific antecedents. Moreover, the changes taking place during the time of separation may effectively dilute or strengthen the setting that prevails at the time of exit. Therefore, the relevance of the exit at the later stages is difficult to predict. Nevertheless, an exit is a critical event that cannot be overlooked. In particular, an exit may become a point of reference for performance both in terms of competences and goodwill. Mariotti and Delbridge (2012) mention past experiences of working together as one key factor in the reestablishment of collaboration, but how the joint work has ended is likely to contribute to the final outcomes.

\subsection{Attributes of exits}

Gidhagen and Havila (2016, 270) suggest that following relationship endings, "many different types of business remains maybe found", including remnants of the earlier relationships (Havila and Wilkinson, 2001). Likewise, remnants of the exit and relationship termination processes (Alajoutsijärvi et al. 2000) may be present. These can affect the likelihood and success of the potential reinstatement of the relationships (see Vaaland and Håkansson, 2003; Zhelyazkov and Gulati, 2016). Tomlinson et al. (2004), for example, refer to the earlier exit strategy as a factor influencing the willingness to reconcile. Furthermore, they bring out probability of future violation as an influencing factor. However, as exits come in different forms (e.g., Pressey and Mathews, 2003), a variety of attributes - and their combinations - need to be acknowledged. From earlier research, predictability, mutuality, reason and tone (as shown in the lower left part of Figure 1) can be identified as relevant dimensions.

First, while some exits are anticipated and planned from the very beginning (Halinen and Tähtinen, 2002), others come more unexpectedly; their predictability varies. The predictability of an exit has an effect on how well the parties can recover from the exit. While readiness to deal with relationship termination is also dependent on the capabilities of the organization, the importance of being able to make proactive adjustments cannot be overlooked. Current literature addressing the outcomes of exit typically considers exit from an ex ante point of view, with 
the focus on whether restoration and continuation of the relationship should be pursued, or if an exit would be a better choice (see, e.g., Havila and Tähtinen, 2002). If such evaluation possibilities are taken away, the nature of the exit changes.

On another dimension, exits differ in terms of mutuality: They can be unilateral or bi/multilateral, meaning that they occur as a result of activities by one or both/all actors (Baxter, 1985; Giller and Matear, 2001; Pressey and Mathews, 2003). For example, it is possible that an actor leaves the network against the expectations and/or will of other network members (and thereby actually generates further instability; see Dahlin and Havila, 2008; Zhelyazkov and Gulati, 2016). In some cases a destructively acting party may be dismissed from a network, whereas in others an (innocent) actor gets discarded against its will (i.e., if one party convinces others in the network to do so). These situations are likely to affect the chances of the different parties to function after the exit, and therefore leave different imprints that may come around again at the time of re-encounters.

The exit reason (related to mutuality but still a separate dimension) varies as well. Exits from initially continuous relationships (Halinen and Tähtinen, 2002; Holmlund and Hobbs, 2009) are generally chosen with one or all parties having a desire to end the relationship (Hocutt, 1998; consider e.g., the illustrative Example 3 on the franchise network where the franchisor was willing to terminate the relationship), or they are unavoidable with external drivers forcing the exit $^{9}$ (e.g., Tidström and Åhman, 2006, refer to 'external reasons'; Consider also e.g., the illustrative Example 2 and the funding problems faced by the industry-academia research consortium). In addition, natural forms of exits may take place with connections becoming obsolete and fading away (Halinen and Tähtinen, 2002; Pressey and Mathews, 2003). This happened in Example 1, where previous collaboration around joint R\&D activities dissolved naturally as a result of increasing divergence in development trajectories and commercial interests of the parties. Again, these alternatives likely yield varying outcomes regarding the following activities of the parting actors. These can then play a role in determining whether or not the parties will interact again, and what kind of a re-encounter situation will take place.

\footnotetext{
${ }^{9}$ The parties may not be enthusiastic about termination, but are also able to see the rationale behind it.
} 
The exit, like re-encounters, can also exhibit different tones. Baxter's (1985) considerations on exit strategies related to dyadic relationships can provide insight into the tone of exit in networks also. First, the exit may be positive or neutral in the sense that actors try to make the exit as easy as possible for others (Baxter, 1985; Pressey and Mathews, 2003). The closer the parties are, the more likely they are to follow such strategies (Gillear and Matear, 2001). On the other hand, the exit may be very much self-oriented - even at the other's cost (Baxter, 1985). Regardless of who actually is responsible for the ending of a relationship, such behavior likely relates to an ending that has a negative tone (Zhelyazkov and Gulati, 2016; Giller and Matear, 2001). Particularly precarious are such situations where the exit is characterized by active attempts to harm the other party (e.g., in the attempt to limit potential competition). There might be inaccurate knowledge spreading in the business environment regarding aspects of the exit, which deteriorates the possibilities of the actors to continue their operations (see Zhelyazkov and Gulati, 2016, on local and global reputation levels). This happened in the case of the discarded franchisee mentioned above (Example 3), where the franchisor spread some bad wordof-mouth following the exit.

One challenge is that the exit situation may be perceived differently at different levels: Extant literature covers inter-organizational, intra-organizational and interpersonal levels (e.g., Alajoutsijärvi, Möller and Tähtinen, 2000; Giller and Matear, 2001; Lind et al., 2000; De Clercq et al., 2009; Das and Teng, 2000). In Example 3, the franchisor, the discarded franchisee and the franchisee's supplier ended up having somewhat different experiences. While the relations between the franchisor and the franchisee were badly hurt at the individual level, the supplier had a different experience. For the supplier, the exit meant change in the form of losing a customer. While the supplier was not happy about this, for them the exit situation was forced and neutral rather than chosen and negative. The supplier also retained the connection with the franchisor. Vorley et al. (2012), and Dahlin and Havila (2008) describe these aspects more generally. What is noteworthy is that exits are likely to set the direction for the next phases for all involved actors, and may even influence their extended networks ${ }^{10}$. Therefore, they will likely surface when actors meet again.

\subsection{Influence of exits on re-encounters and their outcomes}

\footnotetext{
${ }^{10}$ Consider 'domino effects' (Hertz, 1998) or 'netquakes', i.e., a spread of change in business networks initiated by a change in individual relationships: a lot of variation exists, from an exit having no wider effect to dismantling whole networks (Dahlin and Havila, 2008).
} 
When a re-encounter occurs, challenges may emerge if the past burdens the relationships. $\mathrm{Mu}-$ tuality, reasons and the tone of exits can align differently in exit situations, and perceptions on exits can be quite different especially later on (Golden, 1992). The (unplanned) exit easily throws (surprised) actors into a state of confusion and insecurity regarding the ex post exit future (see Zhelyazkov and Gulati, 2015), and the exit therefore gains an important role. Positive approaches toward others during exits have been seen to produce constructive outcomes for the parties involved (Baxter, 1985), and good communication and justified practices can limit and mitigate harmful effects later on (e.g., Koza and Dant, 2007; Mohr and Spekman, 1994).

Earlier research has actually touched upon the effects that exits may have on later re-encounters. Refraining may result from earlier experiences if the re-encounter situation is seen as unattractive due to the earlier exit situation. Poblete et al. $(2014,2)$ point toward this when they suggest that the "relationship's history can [...] be a constraining factor as in some cases disengaging from a business relationship may be such a painful and negative experience (Dwyer et al., 1987) that reactivation may not be an option." The combination of exit attributes can also explain retribution as a re-encounter outcome, especially if the re-encounter situation itself does not support re-establishment of relationships: a chosen, unilateral and negatively loaded exit may give start to revenge, especially if an actor that has been hurt in the process has strengthened its position during the time of separation (see Bass, Barnett and Brown, 1998; Pressey and Mathews, 2003). Considering these issues, actors that build business networks should be careful in bringing such actors to the same table that have a history of notably problematic exits.

However, exits characterized with problems do not necessarily lead to refraining or retribution. Reframing or even full reactivation can be reached if the (potential) past exit-related issues are dealt with efficiently (Blomqvist et al., 2005). Correspondingly, an easy, unproblematic exit does not guarantee a re-establishment of relationships. It can, however, strengthen the likelihood of such outcomes if the re-encounter situation is initially prone to lead to re-activation. It is suggested here that the earlier exit can become a moderating factor with regard the re-encounter outcomes.

\subsection{Influence of the antecedents of exits}


Not only the exits, but also their antecedents depicted in the bottom arrow in Figure 1 may influence re-encounter outcomes. In general, triggers and drivers of relationship termination have been relatively widely examined (Hocutt, 1998; Zhelyazkov and Gulati, 2016; Tidström and Åhman, 2006). These often culminate to conflicts, that is, perceived incompatibilities in the views, interests, or beliefs, held by one or more actors (Jehn, 1995). Hence, conflict is not necessarily a purely negative phenomenon by nature. Prior research indicates that different actors continuously balance between their own goals and those of the networks in which they belong (Husted and Michailova, 2010; Ritala and Hurmelinna-Laukkanen, 2009). While the objectives of the network and individual actors within it are likely well aligned in the beginning of collaboration, it can be expected that at some point this uniformity dissolves, thereby initiating conflict of varying character and severity (Das and Teng, 2000).

First, the importance of the conflict is, of course, a decisive factor, and one that can have far reaching effects: issues without notable relevance to the involved actors are different from those with strategic importance (Edvardsson et al., 2014 use the term 'energy' in the network context). Often, a resulting problematic situation passes without causing serious disturbance, or even ends up strengthening ties (see Blomqvist et al., 2005; Jehn, 1995; 1997; Koza and Dant, 2007). However, also other outcomes may follow. What is also worth noticing is that importance is relative, and even if an issue does not seem as important in one occasion, it may be that actors perceive it differently later on (Golden, 1992).

On another dimension, variation can be found in situational issues, i.e., the substance of conflict (Ford and Havila, 2003). Lumineau et al. (2015) suggest that conflict is ordinarily categorized in terms of competence- and integrity-based failures. Similarly, Salas et al. (2015) suggest that conflict can be task-based, referring to different opinions on the ways to execute tasks (like in Example 4, where the innovation network founder did not approve how the network was being run); relationship-based, indicating that annoyance or tension is present in the (inter-personal) relationships (reflecting on the organizational level; In Example 3, the CEO of the firm annoyed managers in the original franchisor organization by criticising some of their policies and by making development suggestions based on own experimentation); or process-based, referring to differing views on how to divide tasks and responsibilities (Ford and Havila, 2003; Jehn, 1997). This suggests that conflict can be more or less persistent, and that it may therefore come up again in the future. For example, Hadjikhani, Lindh and Thilenius, P. $(2012,134)$ note that "a firm's behaviour in discontinuous relationships [that are weaker and faced with interruptions] 
is guided by the level of trust." If the exit shifts the earlier balance and alters the level of trust between the actors, earlier mistreatments may be forgiven but not forgotten. In particular, integrity- or relationship-based conflict (where trust is potentially damaged) may be more difficult to resolve compared to task- or process-based conflict that can be considered situationspecific and responsive to remedies (see Blomqvist et al., 2005; Vorley et al., 2012).

Third, behavioral aspects may vary across conflict situations. The actions causing conflict (and the subsequent exit) can take the form of freeriding or opportunism, for example, but they may also relate to passive behavior that may result from quite "neutral" issues, such as simply not finding the collaboration or contribution of the other party valuable anymore (Anderson and Jap, 2005; Ganesan et al. 2010). In examining marketing channel, Hibbard, Kumar, and Stern (2001) noted that it is more of a rule than an exception that in collaborative activities some actor eventually acts in a way that others disapprove. This can happen even if the parties seem to be reaching the set goals and nothing is concretely wrong with the relationships (Grayson and Ambler, 1999). In principle, transgression and passivity are equally likely sources of conflict (Hibbard et al., 2001), but they may have different relevance in terms of later re-encounter outcomes: Transgression may bear more negative consequences than a natural tuning down of joint activities (see, e.g., Edvardsson et al., 2014; Zhelyazkov and Gulati, 2016).

While it can be argued that the more recent developments taking place prior to re-encounter likely bear more importance than the past exit and conflicts, these too may become relevant when deciding on how the re-encounter situation is approached and what kind of steps are taken next. The following propositions address this:

Proposition 7a: The combination of predictability, mutuality, reason, and tone of exit may change the development of relationship between re-encounter and re-encounter outcomes Full reactivation is an unlikely outcome of re-encounters when earlier exit is highly problematic (especially for direct ties).

Proposition 7b: The importance, substance, and action related to conflict behind an exit may chance the development of relationship between re-encounter and re-encounter outcomes Full reactivation is an unlikely outcome of re-encounters when earlier conflict is highly problematic (especially for direct ties). 
Proposition 7c: The exit and its antecedents are perceived differently at the individual, organizational, relationship, and network levels - Experiences are most specific and persistent at the individual level, whereas at network level variation exists, and these may even go unnoticed. Proposition 7d: The severity of the exit and its antecedents has an effect on how long they will bear importance.

\section{DISCUSSION AND CONCLUSIONS}

In the beginning of this study, a goal was set to find out how different re-encounter outcomes develop from the earlier network exits and relationship terminations. The underlying goal was to start developing a conceptual framework that would allow more detailed research on reencounters. Understanding the interplay of exit and after-exit processes is valuable, as it may be that those actors who exit the networks affect the faith of the remaining actors later on, or vice versa. After examination of earlier literature and consideration of illustrative examples, it is suggested, first, that the re-encounter situation is a decisive factor. Evaluation of the re-encounter covers different attributes and happens at different levels, and subsequently, (1) refraining from future interaction, (2) retribution, (3) reactivation characterized by reframing, or (4) full reactivation of the earlier relationships and collaboration takes place.

However, mutuality, reason, and tone of a re-encounter are not the only factors to consider. The developments that have taken place during the time of separation contribute to re-enconters and their outcomes especially considering that the balance between the different actors may have changed compared to earlier situations against which evaluation is likely done. Therefore, a recent success (or failure), and notable changes in the characteristics of the parties play a role in determining the direction for different actors. These changes may occur at individual, organizational, relationship or network levels, and may spread across the levels (Dahlin and Havila, 2008; Granovetter, 1985; Nisbett and Ross, 1980). Furthermore, the exit and its antecedents can have quite far reaching effects both in terms of scope (i.e., different levels; see Zhelyazkov and Gulati, 2016) and time (see, e.g., Pick, 2010). Exits and relationship terminations are critical events, and they may therefore leave imprints that spread to varying extent across different levels, and surface when the re-encounter takes place and decisions are made on the subsequent steps.

\subsection{Implications for research}


The preceding discussion and the introduced propositions contribute to existing knowledge in varying ways and, especially, give start to new research endeavors. As noted above, current research is limited in describing and explaining the developments and events taking place postexit in the network context (Gidhagen and Havila, 2014; 2016). In particular, research on reencounters and their outcomes is narrow (see Zhelyazkov and Gulati, 2016) ${ }^{11}$. Against this background, the first contribution relates to conceptually separating re-encounter and its outcomes. While re-encounters are defined as situations in which paths of actors that have been involved in earlier exit cross again, the outcomes cover the subsequent steps regarding network participation and relationship developments. Acknowledging this distinction allows more finegrained analysis of re-encounter outcomes, and can be utilized in future studies as one aspect to study empirically. Relatedly, this study points towards the need to recognize the variety in re-encounter outcomes: Reactivation of business relationships is surely addressed in existing literature, but this also means that research mainly covers situations where (positive) action is taken as a result of earlier collaboration parties coming together again after a period of separation. Other re-encounter situations are rarely acknowledged, and their dynamics are therefore poorly understood. For instance, it may be that a series or re-encounters precedes a re-establishment of network activity (cf. Halinen et al., 1999, on a similar logic regarding multiple developments preceding termination of a relationship), and that each of these contributes to later performance of the network and individual actors. Further research is needed to examine these issues in a detailed manner.

Second, this study contributes to existing research by arguing that a longitudinally and vertically integrated view is needed in order to understand re-encounters and their outcomes. First, despite all the effort put into earlier research, a comprehensive framework is still missing that would connect exits and relationship termination to later partner selection and network formation - or dismissing these activities. Many steps in between still call for more attention and empirical evidence (see, e.g., Gidhagen and Havila, 2014; 2016; Lumineau et al., 2015; Pick et al., 2016). This study introduces a longitudinally integrative approach, as it is argued here that the shadows of the past are of relevance when re-encounter outcomes are determined. Deviating

\footnotetext{
${ }^{11}$ There are good reasons for this: while instances in which re-encounters happen in some form are not uncommon (see Mariotti and Delbridge, 2012), access to a representative data for such cases can be challenging to establish (see Gidhagen and Havila, 2014; 2016; Lumineau, Eckert and Handley, 2015). A further challenge is that different aspects are woven together in complicated ways at various levels (network, relational, organizational and individual, see Lumineau et al., 2015; Mariotti and Delbridge, 2012; Granovetter, 1981).
} 
from a 'regularly described' relationship initiation or partner selection situations where there often is only a brief notion on past events being possibly relevant (or beneficial) somehow (see, e.g., Aarikka-Stenroos, 2008), in re-encounter situations these events, and especially the 'somehow', are central. In particular, it is suggested here (following Gidhagen and Havila, 2016) that the re-encounter situation itself is important, but the earlier exit experiences and the subsequent changes in actor characteristics and performance may strengthen or dilute the likelihood of a specific type of re-encounter leading to a particular outcome. This makes dealing with exits and re-encounters a relevant managerial issue in the network context. The above outlined propositions provide tools for addressing these aspects of network dynamics, turning attention from the business relationship lifecycle to the 'relationship life-circle', and provide one path for future studies to explore.

The propositions and the related discussion also address the need for vertical integration in terms of the level of analysis. While existing literature points towards re-encounters being likely affected by factors residing on different levels of analysis, how they come together is not as obvious from current body of knowledge. A central idea in this paper is that multilevel analysis has the potential to improve understanding beyond knowledge provided in existing research. While only tentative ideas have been included here, it seems that aspects such as persistence of earlier experiences, and the relevance and manageability of competence-based versus relational issues are different depending on which level of analysis they are considered. Future research utilizing multi-level analysis, as well as ideas from neighbouring theoretical streams such as behavioural and network theories, organizational learning, and entrepreneurial opportunities, for example, can shed light on these issues.

\subsection{Implications for practice}

While existing research has already highlighted the importance of planning for exit in order to avoid unwanted outcomes (Gulati et al., 2008; Pick, 2010), this study brings up issues regarding later re-encounters. The conceptual analysis of the dynamics emerging ex post exit provides some advice to actors that are going through exit situations themselves or are overseeing some other actor exiting from their network - especially if future network formation with the same actors is kept as an open possibility; the exit strategy can be seen in a different light. Likewise, the re-encounters could be seen differently, if it is acknowledged that they might reoccur at some point. 
The insights introduced here can also be useful for network orchestrators, and for managers who make decisions on contact persons in collaborative activities especially in re-encounter situations: it may be that individual preferences and experiences unintentionally shift the direction if managerial decisions are made without consideration of "contagious" effects, for example, when selecting and instructing contact persons. This could be an avenue for experimental research, for example.

Moreover, while bridges are sometimes inevitably burned (and while this does not necessarily lead to problems later on), networked environments with direct and indirect ties inherently increase the need for different actors to pay attention to their actions (see e.g., Zhelyazkov and Gulati, 2016, describing the far reaching implications in venture capital syndications). The tentative ideas in this study suggest that one's competence can become decisive regarding whether or not the actors will share the operations environment, and whether or not collaboration restarts - meaning that it pays off to build capabilities at individual and organizational levels. Nevertheless, the tone of coexistence and potential new collaboration is very likely influenced by the earlier experiences and, in particular, partings in different exit situations. Therefore, managers should pay attention to relationship and reputation management at relationship- and network levels, even if it seems that the collaboration has come to an end.

\subsection{Limitations and future research directions}

Like any study, this one has its limitations. An obvious limitation is the conceptual nature of this paper: empirical studies are needed to confirm or refute the propositions that are presented here. Also, while a range of literature is examined for this study, it may be that relevant publications have gone noticed. The broad level of discussion also means that a lot of detail is unavoidably missed. For example, different types of networks may be more or less vulnerable to exits, which also affects the likelihood and types of re-encounters taking place (see, e.g., Möller and Rajala, 2007; Barlow et al., 2013). Likewise, the details of a termination of an individual relationship and ending of multiple relationships simultaneously, or chain reactions triggered by an individual relationship termination, likely vary, generating varying re-encounter situations and outcomes. These aspects should be addressed in future research, building on, e.g., network and relational theories. 
In addition, while categorizing different outcomes of re-encounters and the influencing factors behind them brings up relevant aspects to acknowledge and manage in re-encounter situations, this study only provides an overview; there is still a lot of room for further research. In particular, individual attributes of exists and their interplay in explaining specific re-encounter outcomes invites more research. For example, it needs to be studied if specific types of exits are associated with higher degrees of retribution emerging out of re-encounters, and if other types of exits regularly promote refraining from collaboration. The same applies to the developments taking place during the time of separation. For example, in a situation where one party needs others to start collaborating again, the ways in which bargaining power can be and is utilized on either side may be relevant. Similarly, it may be that a chosen, negative exit quite easily leaves open the possibility of punishment if an opportunity for it arises. In this, resource-based view, and organization and behavioural theories, for instance, may complement knowledge derived from network theories. In-depth case studies analysing individual, organizational, relational, and network-level aspects in relation to re-encounters and their antecedents have the potential to reveal important issues on the emerging dynamics.

Likewise, contingency factors, moderation and mediation effects deserve examination: It could be expected, for example, that with a short time-span, limited changes take place and therefore problematic exits are more likely to facilitate retribution or refraining from interaction as a result of re-encounter. Correspondingly, a positive exit might lose its supporting character if too much time passes and changes become prominent (see Levin et al., 2011; Mariotti and Delbridge, 2012). Time could therefore be an important factor in quantitative research endeavors.

Another interesting avenue for future research might be to see how the processes of exiting and post-exit activities change as the participants become more aware of the prevailing dynamics. Nevertheless, exit, post-exit developments and re-encounters associated with different outcomes can be relevant aspects in the discussion on managing exit, and managing future network formation and management. This study provides the background on which further studies can be conducted.

\section{REFERENCES}


Aarikka-Stenroos, L. (2008), "What really happens in initiation? - Investigating the subprocesses and features of emerging buyer-seller relationships", Proceedings of the $24^{\text {th }}$ IMP Conference, Uppsala, Sweden.

Alajoutsijärvi, K., Möller, K., and Rosenbröijer, C. J. (1999), "Relevance of focal nets in understanding the dynamics of business relationships", Journal of Business-to-Business Marketing, Vol. 6, No. 3, pp. 3-35.

Alajoutsijärvi, K., Möller, K. and Tähtinen, J. (2000),'Beautiful exit: how to leave your business partner", European Journal of Marketing, Vol. 34, pp.1270-1290.

Anderson, J. C., Håkansson, H. and Johanson, J. (1994), "Dyadic business relationships within a business network context", The Journal of Marketing, Vol. 58, pp.1-15.

Anderson, E. and Jap, S. D. (2005), "The dark side of close relationships", MIT Sloan Management Review, Vol. 46, No. 3, pp. 75-82.

Aquino, K., Tripp, T. M., and Bies, R. J. (2001), "How employees respond to personal offense: the effects of blame attribution, victim status, and offender status on revenge and reconciliation in the workplace", Journal of Applied Psychology, Vol. 86, No. 1, pp. 52-59.

Ariño, A., and De La Torre, J. (1998), "Learning from failure: Towards an evolutionary model of collaborative ventures", Organization Science, Vol. 9, No. 3, pp. 306-325.

Bachmann, R., Gillespie, N., and Priem, R. (2015), "Repairing Trust in Organizations and Institutions: Toward a Conceptual Framework", Organization Studies, Vol. 36, No. 9, pp. 11231142 .

Barlow, J., Roehrich, J. and Wright, S. (2013), "Europe sees mixed results from publicprivate partnerships for building and managing health care facilities and services", Health Affairs, Vol. 32, No.1, pp.146-154.

Bass, K., Barnett, T. and Brown, G. (1998), "The moral philosophy of sales managers and its influence on ethical decision making”, Journal of Personal Selling \& Sales Management, Vol. 18, No. 2, pp. 1-17.

Batonda, G. and Perry, C. (2003), "Approaches to relationship development processes in inter-firm networks", European Journal of Marketing, Vol. 37, No. 10, pp. 1457-1484.

Baxter, L.A. (1985), “Accomplishing relationship disengagement”, in: Duck, S. and Perlman, D. (Eds), Understanding Personal Relationships. An Interdisciplinary Approach, Sage, London, pp. 243-265.

Bergenholtz, C., and Waldstrøm, C. (2011), "Inter-organizational network studies-a literature review", Industry and Innovation, Vol. 18, No. 6, pp. 539-562. 
Bliemel, M. (2011), "Entrepreneurial Network Development: The Role of Dormant Relationships and Luck", In: Australian and New Zealand Academy of Management Conference, Wellington, 7 - 9 December 2011.

Blomqvist, K., Hurmelinna, P. and Seppänen, R. (2005) "Playing the Collaboration Game Right - Balancing Trust and Contracting”, Technovation, Vol. 25, No. 5, pp. 497-504.

Brass, D. J., Butterfield, K. D. and Skaggs, B. C. (1998) "Relationships and unethical behavior: A social network perspective", Academy of Management Review, Vol. 23 No. 1, pp. 14-31.

Brattström, A., Carlsson-Wall, M., Faems, D. and Mähring, M. (2013), "Inter-firm relational roller coasters: a process perspective on trust repair in alliances", In: Academy of Management Proceedings (Vol. 2013, No. 1, p. 12307). Academy of Management.

Chou, H.H., \& Zolkiewski, J. (2012), "Decoding network dynamics”, Industrial Marketing Management, Vol. 41, No. 2, pp. 247-258.

Collins, J. D. and Hitt, M. A. (2006), "Leveraging tacit knowledge in alliances: The importance of using relational capabilities to build and leverage relational capital", Journal of Engineering and Technology Management, Vol. 23, No., 3, pp. 147-167.

Coughlan, P, Coghlan, D. and Lombard, F. (2003), "Managing collaborative relationships in a period of discontinuity", International Journal of Operations \& Production Management, Vol. 23, No. 10, pp. 1246-1259.

Dahlin, P. and Havila, V. (2008), "Network Connectivity and Business Netquakes-Ways to Understand the Spread of Change”, In: 24th Annual IMP Conference, Uppsala, 4-6 september.

Das, T. K. and Teng, B. S. (2000), "Instabilities of strategic alliances: An internal tensions perspective", Organization science, Vol. 11, No. 1, pp. 77-101.

De Clercq, D., Thongpapanl, N. and Dimov, D. (2009), "When good conflict gets better and bad conflict becomes worse: the role of social capital in the conflict-innovation relationship", Journal of the Academy of Marketing Science, Vol. 37, No. 3, pp. 283-297.

Dhanaraj, C. and Parkhe, A. (2006), "Orchestrating innovation networks", Academy of Management Review, Vol. 31, pp. 659-669.

Dirks, K. T., Lewicki, R. J. and Zaheer, A. (2009), "Reparing relationships within and between organizations: Building a conceptual foundation”, Academy of Management Review, Vol. 34, No. 1, pp. 68-84. 
Duck, S. (1982), “A topography of relationship disengagement and dissolution”, In: Duck, S. (Ed.) Personal Relationships 4: Dissolving Personal Relationships, Academic Press, London, pp. 1-30.

Dwyer, F.R., Schurr, P.R., and Oh, S. (1987), "Developing buyer-seller relationships", Journal of Marketing, Vol. 51, pp. 11-27.

Dyer, J. H., and Singh, H. (1998), “The relational view: Cooperative strategy and sources of interorganizational competitive advantage", Academy of management review, Vol. 23, No.4, pp. 660-679.

Eckerd, S., and Handley, S. (2015), “To Err Is Human: A Model of Interorganizational Violations and Repair", Academy of Management Proceedings, Vol. 2015, No. 1, p. 14978.

Edvardsson, B., Holmlund, M., and Strandvik, T. (2008). "Initiation of business relationships in service-dominant settings", Industrial Marketing Management, Vol. 37, No. 3, pp. 339-350.

Edvardsson, B., Kowalkowski, C., Strandvik, T. and Voima, P. (2014), "Negative critical waves in business relationships: an extension of the critical incident perspective", The Journal of Business \& Industrial Marketing, Vol. 29, No. 4, pp. 284-294.

Faems D, Janssens M, Madhok A and van Looy B. (2008). "Toward an integrative perspective on alliance governance: Connecting contract design, trust dynamics, and contract application", Academy of Management Journal, Vol. 51, No. 6, pp. 1053-1078.

Ford, D. and Havila, V. (2003), "Problems in relationships: When it all goes wrong”, In: 19th IMP Conference, Lugano, Switzerland.

Ford, D. and Rosson, P.J. (1982), "The relationships between export manufacturers and their overseas distributors", In: Export Management, (Eds. Czinkota, M. and Tesar, G.), Praeger, New York, NY, pp. 257-75.

Fors, J. and Nyström, A. G. (2009), “Network reactions to actor's role change”. Proceedings of 25th IMP Conference. 3- 5 September, 2009, Marseille, France.

Ganesan, S., Brown, S. P., Mariadoss, B. J., and Ho, H. (2010), "Buffering and amplifying effects of relationship commitment in business-to-business relationships", Journal of Marketing Research, Vol. 47, No. 2, pp. 361-373.

Garland, H. (1990), "Throwing good money after bad: The effect of sunk costs on the decision to esculate commitment to an ongoing project", Journal of Applied Psychology, Vol. 75, No. 6, pp. 728-731.

Gidhagen, M. and Havila, V. (2014), "Resuming ended business relationships: The impact of relationship remains", In: Proceedings of the 30th IMP Conference, Bordeaux, France 2014. 
Gidhagen, M. and Havila, V. (2016), "From Business Remains to Reactivated Relationships", In: P.Thilenius, C. Pahlberg and V. Havila (Eds.) Extending the Business Network Approach Palgrave Macmillan, UK, pp. 269-282.

Giller, C. and Matear, S. (2001), "The termination of inter-firm relationships", Journal of Business \& Industrial Marketing, Vol. 16, No. 2, pp. 94-112.

Golden, B.R. (1992), "The past is past - or is it? The use of retrospective accounts as indicators of past strategy", Academy of Management Journal, Vol. 35, pp. 848-860.

Granovetter, M. (1981), The strength of weak ties: A network theory revisited. New York: State University of New York, Department of Sociology.

Granovetter, M. (1985), "Economic action and economic structure: the problem of embeddedness", American Journal of Sociology, Vol. 91, pp. 481-510.

Grayson, K. and Ambler, T. (1999), "The dark side of long-term relationships in marketing services", Journal of Marketing Research, Vol. 36, No. 1, pp. 132-141.

Griffith, D.A., Harvey, M.G. and Lusch, R.F. (2006), "Social exchange in supply chain relationships: The resulting benefits of procedural and distributive justice", Journal of Operations Management, Vol. 24, pp. 85-98.

Gulati, R. (1995), "Social structure and alliance formation patterns: A longitudinal analysis", Administrative science quarterly, Vol. 40, pp. 619-652.

Gulati, R. (1998), “Alliances and networks”, Strategic Management Journal, Vol. 19, No. 4, pp. 293-317.

Gulati, R., Nohria, N. and Zaheer, A. (2000), 'Strategic networks', Strategic Management Journal, Vol. 21 No. 3, pp. 203-15.

Gulati, R., Sytch, M. and Mehrotra, P. (2008), "Breaking up is never easy: Planning for exit in a strategic alliance", California Management Review, Vol. 50, No. 4, pp. 147-163.

Guler, I. (2007), "Throwing good money after bad? Political and institutional influences on sequential decision making in the venture capital industry", Administrative Science Quarterly, Vol. 52, No. 2, pp. 248-285.

Hadjikhani, A. (1996), "Project marketing and the management of discontinuity", International Business Review, Vol. 5, No. 3, pp. 319-336

Hadjikhani, A., Lindh, C. and Thilenius, P. (2012), “The impact of discontinuity on firms' business relationship behaviour", European Business Review, Vol. 24, No. 2, pp. 134-150.

Halinen, A., Salmi, A. and Havila, V. (1999), "From dyadic change to changing business networks: an analytical framework", Journal of Management Studies, Vol 36, No. 6, p. 779794. 
Halinen, A. and Tähtinen, J. (2002), “A process theory of relationship ending”, International Journal of Service Industry Management, Vol. 13, No. 2, pp. 163-180.

Havila, V. and Wilkinson, I. (2002). "The principle of conservation of business relationship energy: or many kinds of new beginnings", Industrial Marketing Management, Vol. 31, pp. 191-203.

Hertz, S. (1998), "Domino Effects in International Networks", Journal of Business to Business Marketing, Vol. 5, No. 3, pp. 3-31.

Hibbard, J. D., Kumar, N. and Stern, L. W. (2001), "Examining the impact of destructive acts in marketing channel relationships", Journal of Marketing Research, Vol. 38, No. 1, pp. 45-61.

Hinterhuber, A. (2002), "Value chain orchestration in action and the case of the global agrochemical industry", Long Range Planning, Vol. 35, No. 6, pp. 615-635.

Hocutt, M.A. (1998), "Relationship dissolution model: antecedents of relationship commitment and the likelihood of dissolving a relationship", International Journal of Service Industry Management, Vol. 9, No. 2, pp. 189-200.

Holmlund, M. and Hobbs, P. (2009), "Seller-initiated relationship ending: An empirical study of professional business-to-business services", Managing Service Quality: An International Journal, Vol. 19, No. 3, pp. 266-285.

Holmlund-Rytkönen, M. and Strandvik, T. (2005), "Stress in business relationships", Journal of Business \& Industrial Marketing, Vol. 20, No. 1, pp. 12-22.

Husted, K. and Michailova, S. (2010), "Dual allegiance and knowledge sharing in interfirm R\&D collaborations", Organizational Dynamics, Vol. 39, No. 1, pp. 37-47.

Håkansson, H. and Ford, D. (2002), "How should companies interact in business networks?” Journal of Business Research, Vol. 55, pp. 133-139.

Håkansson, H. and Snehota, I. (1989), "No business is an island: the network concept of business strategy”, Scandinavian Journal of Management, Vol. 5, No. 3, pp. 187-200.

Jarillo, J.C. (1988), “'On strategic networks”, Strategic Management Journal, Vol. 9 No. 1, pp. 31-41.

Jehn, K. A. (1995), "A multimethod examination of the benefits and detriments of intragroup conflict”, Administrative Science Quarterly, Vol. 40, No. 2, pp. 256-282.

Jehn, K. A. (1997), “A qualitative analysis of conflict types and dimension in organizational groups", Administrative Science Quarterly, Vol. 42, No. 3, pp. 530-557. 
Jones, M.A., Mothersbaugh, D.L. and Beatty, S.E. (2002), “Why customers stay: measuring the underlying dimensions of services switching costs and managing their differential strategic outcome", Journal of Business Research, Vol. 55, No. 6, pp. 441-50.

Joshi, A. W. and Stump, R. L. (1999). "The contingent effect of specific asset investments on joint action in manufacturer-supplier relationships: An empirical test of the moderating role of reciprocal asset investments, uncertainty, and trust", Journal of the Academy of Marketing Science, Vol. 27, No. 3. pp. 291.

Kamp, B. (2005), "Formation and evolution of buyer-supplier relationships: Conceiving dynamism in actor composition of business networks", Industrial Marketing Management, Vol. 34, No. 7, pp. 658-668.

Keyton, J. (1993), "Group termination. Completing the study of group development", Small Group Research, Vol. 24, No. 1, pp. 84-100.

Koza, K. L. and Dant, R. P. (2007), "Effects of relationship climate, control mechanism, and communications on conflict resolution behavior and performance outcomes", Journal of Retailing, Vol. 83, No. 3, pp. 279-296.

Krafft, M. and Pick, D. (2007), "General willingness to reactivate a former relationship. A customer survey and experiment", Proceedings of the 36th European Marketing Conference $(E M A C)$, Reykjavik, Iceland.

Lavie, D. (2006), "The competitive advantage of interconnected firms: An extension of the resource-based view", Academy of Management Review, Vol. 31, No. 3, pp. 638-658.

Levin, D. Z., Walter, J. and Murnighan, J. K. (2011), "Dormant ties: The value of reconnecting”, Organization Science, Vol. 22, No. 4, pp. 923-939.

Li, D., Eden, L., Hitt, M. A. and Ireland, R. D. (2008), "Friends, acquaintances, or strangers? Partner selection in R\&D alliances", Academy of Management Journal, Vol. 51, No. 2, pp. 315-334.

Li, S. X. and Rowley, T. J. (2002), "Inertia and evaluation mechanisms in interorganizational partner selection: Syndicate formation among US investment banks", Academy of Management Journal, Vol. 45, No. 6, pp. 1104-1119.

Lind, E. A., Greenberg, J., Scott, K. S. and Welchans, T. D. (2000), "The winding road from employee to complainant: Situational and psychological determinants of wrongful-termination claims”, Administrative Science Quarterly, Vol. 45, No. 3, pp. 557-590.

Lopes, L., Brito, C. and Alves, H. (2013), "Customer relationship reactivation in the telecommunications sector", Proceedings of the 3rd INBAM Conference. International Network of Business and Management Journals. 
Lumineau, F., Eckerd, S., and Handley, S. (2015), "Inter-Organizational Conflicts: Research Overview, Challenges, and Opportunities", Journal of Strategic Contracting and Negotiation, Vol. 1, No. 1, pp. 42-64.

Ma, X., Yao, X., and Xi, Y. (2009), "How do interorganizational and interpersonal networks affect a firm's strategic adaptive capability in a transition economy?", Journal of Business Research, Vol. 62, No. 11, pp. 1087-1095.

Mariotti, F. and Delbridge, R. (2012), "Overcoming network overload and redundancy in interorganizational networks: The roles of potential and latent ties", Organization Science, Vol. 23, No. 2, pp. 511-528.

Michailova, S. and Paul, S. (2014), "To orchestrate MNC intra-firm relationships, one needs to understand them", Advances in International Management, Vol. 27, pp. 377-402.

Mitrega, M., Forkmann, S., Ramos, C. and Henneberg, S. C. (2012). "Networking capability in business relationships-Concept and scale development", Industrial Marketing Management, Vol. 41, pp. 739-751.

Mohr, J. and Robert E. Spekman (1994). "Characteristics of partnership success: partnership attributes, communication behavior and conflict resolution techniques," Strategic Management Journal, Vol. 15, pp. 135-152

Möller, K. and Halinen, A. (1999), "Business Relationships and Networks: Managerial Challenge of Network Era”, Industrial Marketing Management, Vol. 28, No. 5, pp. 413-427.

Möller, K and Rajala, A. (2007), "Rise of strategic nets - New modes of value creation", Industrial Marketing Management, Vol. 36, pp. 895-908.

Nisbett, R. and Ross, L. (1980), Human inference: Strategies and shortcomings of human judgment. Englewook Cliffs, NJ: Prentince-Hall.

O’Grady J. D. (2009) Apple Inc. Westport, Greenwood Press

Nätti, S., Hurmelinna-Laukkanen, P. and Johnston, W. (2014), “Absorptive capacity and network orchestration in innovation communities - Promoting service innovation", Journal of Business and Industrial Marketing, Vol. 29, No. 2, pp. 173 - 184

Oliver, A. L. and Ebers, M. (1998), "Networking network studies: an analysis of conceptual configurations in the study of inter-organizational relationships", Organization studies, Vol. 19, No. 4, pp. 549-583.

Oyer, P. and Schaefer, S. (2000), "Layoffs and Litigation", RAND Journal of Economics, Vol. 31, No. 2, pp. 345-358. 
Peng, M. W. and Luo, Y. (2000), "Managerial ties and firm performance in a transition economy: The nature of a micro-macro link", Academy of Management Journal, Vol. 43, No. 3, pp. 486-501.

Pick, D. (2010), "Never say never-Status quo and research agenda for relationship termination in b2b markets", Journal of Business Market Management, Vol. 4, No. 2, pp. 91-108.

Pick, D., Thomas, J. S., Tillmanns, S. and Krafft, M. (2016), "Customer win-back: the role of attributions and perceptions in customers' willingness to return", Journal of the Academy of Marketing Science, Vol. 44, No. 2, pp. 218-240.

Ping, R. and Dwyer, F.R. (1992), "A preliminary model of relationship termination in marketing channels", In: Frazier, G.L. (Ed.), Advances in Distribution Channel Research, Vol. 1, JAI Press, Greenwich, CT, pp. 215-33.

Poblete, L., Bengtson, A., and Havila, V. (2014), "What do we know about the re-activation of business relationships?". In: 30th Annual IMP Conference, Bordeaux, France, 1-6 September 2014.

Pressey, A. D., and Mathews, B. P. (2003), "Jumped, pushed or forgotten? Approaches to dissolution", Journal of Marketing Management, Vol. 19, No. 1-2, pp. 131-155.

Provan, K.G., Fish, M.A. and Sydow, J. (2007), "Interorganizational networks at the network level: A review and commentary on the empirical literature", Journal of Management, Vol. 33, pp. 479-516.

Rerup, C. (2005), "Learning from past experience: Footnotes on mindfulness and habitual entrepreneurship", Scandinavian Journal of Management, Vol. 21, No. 4, pp. 451-472.

Ring, P. S. and Van de Ven, A. H. (1994), "Developmental Processes of Cooperative Interorganizational Relationships”, Academy of Management Review, Vol. 19, No. 1, pp. 90118.

Ritala, P. and Hurmelinna-Laukkanen, P. (2009), "What's in it for me? Creating and appropriating value in innovation-related coopetition", Technovation, Vol. 29, No. 12, pp. 819828.

Ritter, T. (1999), “The networking company: antecedents for coping with relationships and networks effectively", Industrial Marketing Management, Vol. 28, pp. 467-479.

Ritter, T. (2000), "A framework for analyzing interconnectedness of relationships", Industrial Marketing Management, Vol. 29, No. 4, pp. 317-326.

Ritter, T., Wilkinson, I. F. and Johnston, W. J. (2004), "Managing in complex business networks", Industrial marketing management, Vol. 33, No. 3, pp. 175-183. 
Rocha, V., Carneiro, A. and Varum, C. A. (2013), "Serial entrepreneurship, learning by doing and self-selection”. (No. 1312). Universidade do Porto, Faculdade de Economia do Porto.

Roehrich, J. K., Lewis, M. A., and George, G. (2014), “Are public-private partnerships a healthy option? A systematic literature review", Social Science \& Medicine, Vol. 113, pp.110119.

Roos, I. (1999), "Switching processes in customer relationships", Journal of Service Research, Vol. 2, No. 1, pp. 68-85.

Rowley, T. J., Greve, H. R., Rao, H., Baum, J. A., and Shipilov, A. V. (2005), "Time to break up: Social and instrumental antecedents of firm exits from exchange cliques", Academy of Management Journal, Vol. 48, No. 3, pp. 499-520.

Salas, E., Shuffler, M. L., Thayer, A. L., Bedwell, W. L. and Lazzara, E. H. (2015), “Understanding and improving teamwork in organizations: a scientifically based practical guide", Human Resource Management, Vol. 54, No. 4, pp. 599-622.

Salo, A., Tähtinen, J. and Ulkuniemi, P. (2009), "Twists and turns of triadic business relationship recovery", Industrial Marketing Management, Vol. 38, No. 6, pp. 618-632.

Sarasvathy, S. D., Menon, A. R. and Kuechle, G. (2013), "Failing firms and successful entrepreneurs: Serial entrepreneurship as a temporal portfolio", Small Business Economics, Vol. 40, No. 2, pp. 417-434.

Shipilov, A.V. and Li, S.X. (2012), "The missing link: The effect of customers on the formation of relationships among producers in the multiplex triads", Organization Science, Vol. 23, No. 2, pp. 472-491

Skaates, M. A., Tikkanen, H. and Lindblom, J. (2002), "Relationships and project marketing success", Journal of Business \& Industrial Marketing, Vol. 17, No. 5, pp. 389-406.

Tidström, A., and Åhman, S. (2006), “The process of ending inter-organizational cooperation”, Journal of Business \& Industrial Marketing, Vol. 21, No. 5, pp. 281-290.

Tokman, M., Davis, L. M. and Lemon, K. N. (2007), "The WOW factor: Creating value through win-back offers to reacquire lost customers", Journal of Retailing, Vol. 83, No. 1, pp. 47-64.

Tomlinson, E. C., Dineen, B. R., and Lewicki, R. J. (2004), “The road to reconciliation: Antecedents of victim willingness to reconcile following a broken promise", Journal of Management, Vol. 30, No. 2, pp. 165-187.

Tripp, T. M., Bies, R. J. and Aquino, K. (2002), "Poetic justice or petty jealousy? The aesthetics of revenge", Organizational Behavior and Human Decision Processes, Vol. 89, No. 1, pp. 966-984. 
Tähtinen, J. (2002), “A business relationship ending process: stages and actors”, Proceedings of the 18th Annual IMP Conference, Dijon.

Tähtinen, J. and Vaaland, T.I. (2006), "Business relationships facing the end: why restore them?", Journal of Business \& Industrial Marketing, Vol. 21, No. 1, pp. 14 - 23

Ucbasaran, D., Shepherd, D. A., Lockett, A. and Lyon, S. J. (2013), “Life after business failure: The process and consequences of business failure for entrepreneurs", Journal of Management, Vol.39, No. 1, pp.163-202.

Uzzi, B. (1997), "Social structure and competition in interfirm networks: The paradox of embeddedness", Administrative science quarterly, Vol. 42, pp. 35-67.

Vaaland, T.I. and Håkansson, H. (2003), "Exploring interorganizational conflict in complex projects”, Industrial Marketing Management, Vol. 32, pp. 127-138.

Vaaland, T. I., Purchase, S. and Olaru, D. (2005), "When techno-innovative relationships break up - what happens to the network?” International Journal of Innovation \& Technology Management, Vol. 2, No. 3, pp. 293-312.

van der Borgh, M., Cloodt, M. and Romme, A. G. L. (2012), "Value creation by knowledge-based ecosystems: evidence from a field study", $R \& D$ Management, Vol. 42, No., pp. 150-169.

Vorley, T., Mould, O. and Courtney, R. (2012), "My networking is not working! Conceptualizing the latent and dysfunctional dimensions of the network paradigm”, Economic Geography, Vol. 88, No. 1, pp. 77-96.

Wu, C., and Barnes, D. (2011), "A literature review of decision-making models and approaches for partner selection in agile supply chains", Journal of Purchasing and Supply Management, Vol. 17, No. 4, pp. 256-274.

Zaheer, A., Gözübüyük, R. and Milanov, H. (2010), "It's the connections: The network perspective in interorganizational research", The Academy of Management Perspectives, Vol. 24, No. 1, pp. 62-77.

Zhang, C., Griffith, D. A., and Cavusgil, S. T. (2006), "The litigated dissolution of international distribution relationships: A process framework and propositions", Journal of International Marketing, Vol. 14, No. 2, pp. 85-115.

Zhelyazkov, P.I. and Gulati, R. (2016), “After the break-up: The relational and reputational consequences of withdrawals from venture capital syndicates", Academy of Management Journal, Vol. 59, No. 1, pp. 277-301. 
Zheng, J., Roehrich, J. K. and Lewis, M. A. (2008), "The dynamics of contractual and relational governance: evidence from long-term public-private procurement arrangements", Journal of Purchasing and Supply Management, Vol. 14, No. 1, pp. 43-54.

Welch, C.L. and Welch, L.S. (2009), "Re-internationalisation: Exploration and conceptualisation", International Business Review, Vol. 18, No. 6, pp. 567-577.

Wood, M.S. and Karau, S.J. (2009), "Preserving employee dignity during the termination interview: An empirical examination", Journal of Business Ethics, Vol. 86, No. 4, pp. 519-534. 
Appendix. Summary table of illustrative examples.

\begin{tabular}{|c|c|c|}
\hline Example/ phase & $\begin{array}{l}\text { Theoretical concepts } \\
\text { (cf. Figure 1) }\end{array}$ & Relevant levels \\
\hline \multicolumn{3}{|c|}{ Example 1: Medical product developer } \\
\hline $\begin{array}{l}\text { Joint R\&D activities dissolve as a re- } \\
\text { sult of increasing divergence in devel- } \\
\text { opment trajectories of Medical product } \\
\text { developer and its foreign partner }\end{array}$ & $\begin{array}{l}\text { Attributes of exit } \\
-\quad \text { reason: natural } \\
-\quad \text { tone: neutral }\end{array}$ & relationship \\
\hline $\begin{array}{l}\text { Medical device developer creates a } \\
\text { valuable innovation and applies for a } \\
\text { patent }\end{array}$ & $\begin{array}{l}\text { Ex post exit developments } \\
-\quad \text { actor success }\end{array}$ & organization \\
\hline $\begin{array}{l}\text { Earlier partner learns about the inno- } \\
\text { vation and contacts the Medical device } \\
\text { developer with the hopes of re-estab- } \\
\text { lishing joint activities; No opportunity } \\
\text { is perceived by Medical device devel- } \\
\text { oper, and earlier partner copies the in- } \\
\text { novation (claiming the patent invalid) } \\
\text { - Medical device developer needs to } \\
\text { raise patent infringement suit }\end{array}$ & $\begin{array}{ll}\text { Re-encounter } \\
\text { - } & \text { mutuality: one-sided } \\
\text { - } & \text { reason: opportunity-based } \\
& \text { (from the side of earlier } \\
\text { partner) } ¥ \text { need-based } \\
\text { (from the side of Medical } \\
\text { device developer; espe- } \\
\text { cially regarding dispute } \\
\text { settlement) } \\
\text { - } \quad \text { tone: negative }\end{array}$ & $\begin{array}{l}\text { organization - } \\
\text { relationship }\end{array}$ \\
\hline $\begin{array}{l}\text { Top management of earlier partner } \\
\text { changes AND patent dispute is settled } \\
\text { (necessitating collaboration) }\end{array}$ & $\begin{array}{l}\text { Re-encounter outcomes (final) } \\
\quad-\quad \text { reframing }\end{array}$ & $\begin{array}{l}\text { individual - } \\
\text { organization - } \\
\text { relationship } \\
\end{array}$ \\
\hline \multicolumn{3}{|c|}{ Example 2: Research consortium } \\
\hline $\begin{array}{l}\text { A number of members of a research } \\
\text { consortium need to leave the network } \\
\text { as a result of external funding being } \\
\text { withdrawn }\end{array}$ & $\begin{array}{ll}\text { Attributes of exit } \\
\text { - } & \text { predictability: } \\
& \text { unpredictable } \\
\text { - } & \text { reason: unavoidable } \\
\text { - } & \text { tone: neutral }\end{array}$ & network \\
\hline $\begin{array}{l}\text { Academic researchers continue with a } \\
\text { limited number of companies; dis- } \\
\text { carded companies develop their own } \\
\text { network }\end{array}$ & $\begin{array}{c}\text { Ex post exit developments } \\
-\quad \text { changes in network char- } \\
\text { acteristic: limited (survival } \\
\text { of network and actors; ex- } \\
\text { ternal obstacles remain) }\end{array}$ & $\begin{array}{l}\text { organization - } \\
\text { relationship - } \\
\text { network }\end{array}$ \\
\hline $\begin{array}{l}\text { Actors come together occasionally; } \\
\text { funding problems remain }\end{array}$ & $\begin{array}{l}\text { Re-encounter outcomes } \\
-\quad \text { refraining } \\
\text { ( } \neq \text { reframing/ full reacti- } \\
\text { vation awaits removal of } \\
\text { external obstacles) }\end{array}$ & $\begin{array}{l}\text { relationship - } \\
\text { network }\end{array}$ \\
\hline \multicolumn{3}{|c|}{ Example 3: Franchise firm } \\
\hline $\begin{array}{l}\text { A franchise firm in a retail chain pro- } \\
\text { motes its development ideas strongly } \\
\text { and fails to follow all policies of fran- } \\
\text { chisor (taking a critical approach to } \\
\text { some franchisor practices) }\end{array}$ & $\begin{array}{l}\text { Source of conflict } \\
-\quad \text { substance: relationship- } \\
\text { based conflict }\end{array}$ & $\begin{array}{l}\text { individual - } \\
\text { organization - } \\
\text { relationship }\end{array}$ \\
\hline
\end{tabular}




\begin{tabular}{|c|c|c|}
\hline $\begin{array}{l}\text { Although successful, the firm's fran- } \\
\text { chise contract is not renewed; the firm } \\
\text { is discarded from the franchise net- } \\
\text { work; franchisor spreads bad word on } \\
\text { the firm }\end{array}$ & $\begin{array}{cl}\text { Attributes of exit: } \\
\text { - } & \text { predictability: } \\
& \text { unpredictable } \\
- & \text { mutuality: one-sided } \\
- & \text { reason: chosen } \\
- & \text { tone: negative } \\
& \\
- & \text { reason: unavoidable } \\
\text { - } & \text { tone: neutral }\end{array}$ & $\begin{array}{l}\text { individual - } \\
\text { relationship - } \\
\text { network }\end{array}$ \\
\hline $\begin{array}{l}\text { Firm gets a new franchise contract } \\
\text { with another franchisor soon after } \\
\text { learning about the end of first contract; } \\
\text { Supplier continues to collaborate with } \\
\text { franchisor; } \\
\text { Relationship with another franchisee } \\
\text { in the original retail chain is main- } \\
\text { tained; } \\
\text { Earlier franchisor (with notable market } \\
\text { power) expects various suppliers not } \\
\text { to deliver to the firm as a condition of } \\
\text { continuing to collaborate with them }\end{array}$ & $\begin{array}{l}\text { Ex post exit developments } \\
\text { - } \quad \text { actor and network success } \\
\text { - challenges for firm due } \\
\text { to limited access to suppli- } \\
\text { ers } \\
\text { - } \\
\text { changes in actor/network } \\
\text { attributes: limited }\end{array}$ & $\begin{array}{l}\text { individual - } \\
\text { organization - } \\
\text { network }\end{array}$ \\
\hline $\begin{array}{l}\text { Firm and earlier franchisor, and sup- } \\
\text { plier meet infrequently at trade fairs } \\
\text { and other events common to the indus- } \\
\text { try } \\
\text { Firm contacts supplier with purchase } \\
\text { intent }\end{array}$ & $\begin{array}{ll}\text { Re-encounter } \\
-\quad \text { reason: random } \\
\text { - } \quad \text { tone: neutral/negative } \\
\\
\text { - } \quad \text { reason: need-based } \\
-\quad \text { tone: neutral } \\
\end{array}$ & $\begin{array}{l}\text { organization - } \\
\text { network }\end{array}$ \\
\hline $\begin{array}{l}\text { Firm might benefit from re-joining the } \\
\text { original franchise network, but per- } \\
\text { sonal grudge between managers limits } \\
\text { these possibilities together with the } \\
\text { new franchise contract; } \\
\text { Another franchisee from the original } \\
\text { network, with which Firm still has a } \\
\text { relationship, falls into problems. It is } \\
\text { quite obvious that connection to the } \\
\text { firm eventually contributes to the an- } \\
\text { other franchisor being removed from } \\
\text { the network also } \\
\text { Supplier would be willing, but is not } \\
\text { able to collaborate with the firm due to } \\
\text { its connection to the earlier franchisor }\end{array}$ & $\begin{array}{ll}\text { Re-encounter outcome } \\
-\quad \text { refraining } \\
-\quad \text { retribution }\end{array}$ & $\begin{array}{l}\text { individual - } \\
\text { relationship }\end{array}$ \\
\hline \multicolumn{3}{|c|}{ Example 4: Innovation network } \\
\hline $\begin{array}{l}\text { A founder of an innovation promoting } \\
\text { network feels that the network is taken } \\
\text { to wrong direction by network opera- } \\
\text { tives }\end{array}$ & $\begin{array}{l}\text { Source of conflict: } \\
-\quad \text { task-based }\end{array}$ & individual \\
\hline
\end{tabular}




\begin{tabular}{|c|c|c|}
\hline $\begin{array}{l}\text { The network founder leaves the net- } \\
\text { work }\end{array}$ & $\begin{array}{l}\text { Attributes } \\
\quad-\quad \text { mutuality: one-sided } \\
\text { - } \\
\text { - } \text { reason: chosen } \\
\text { tone: negative }\end{array}$ & individual \\
\hline $\begin{array}{l}\text { The network founder joins a success- } \\
\text { ful and interesting organization }\end{array}$ & $\begin{array}{l}\text { Ex post exit developments } \\
-\quad \text { actor success } \\
-\quad \text { no notable changes (apart } \\
\quad \text { from founder having a } \\
\quad \text { new organization) }\end{array}$ & $\begin{array}{l}\text { individual - } \\
\text { organizational }\end{array}$ \\
\hline $\begin{array}{l}\text { Network representatives wish to in- } \\
\text { volve the founder's new organization } \\
\text { in their activities }\end{array}$ & $\begin{array}{ll}\text { Re-encounter } \\
-\quad \text { mutuality: one-sided } \\
\text { - } & \text { reason: opportunity-based } \\
& \text { (from the side of the net- } \\
& \text { work) } \\
\text { - } & \text { tone: neutral/negative (due } \\
& \text { to prevailing attitudes) }\end{array}$ & $\begin{array}{l}\text { individual - } \\
\text { organization - } \\
\text { network }\end{array}$ \\
\hline $\begin{array}{l}\text { Organization of the network founder } \\
\text { avoids collaboration }\end{array}$ & $\begin{array}{l}\text { Re-encounter outcome: } \\
\quad-\quad \text { refraining }\end{array}$ & $\begin{array}{l}\text { individual - } \\
\text { relationship - } \\
\text { network }\end{array}$ \\
\hline
\end{tabular}

